Prepared in cooperation with the Navajo Nation

\title{
Historical Channel-Planform Change of the Little Colorado River near Winslow, Arizona
}

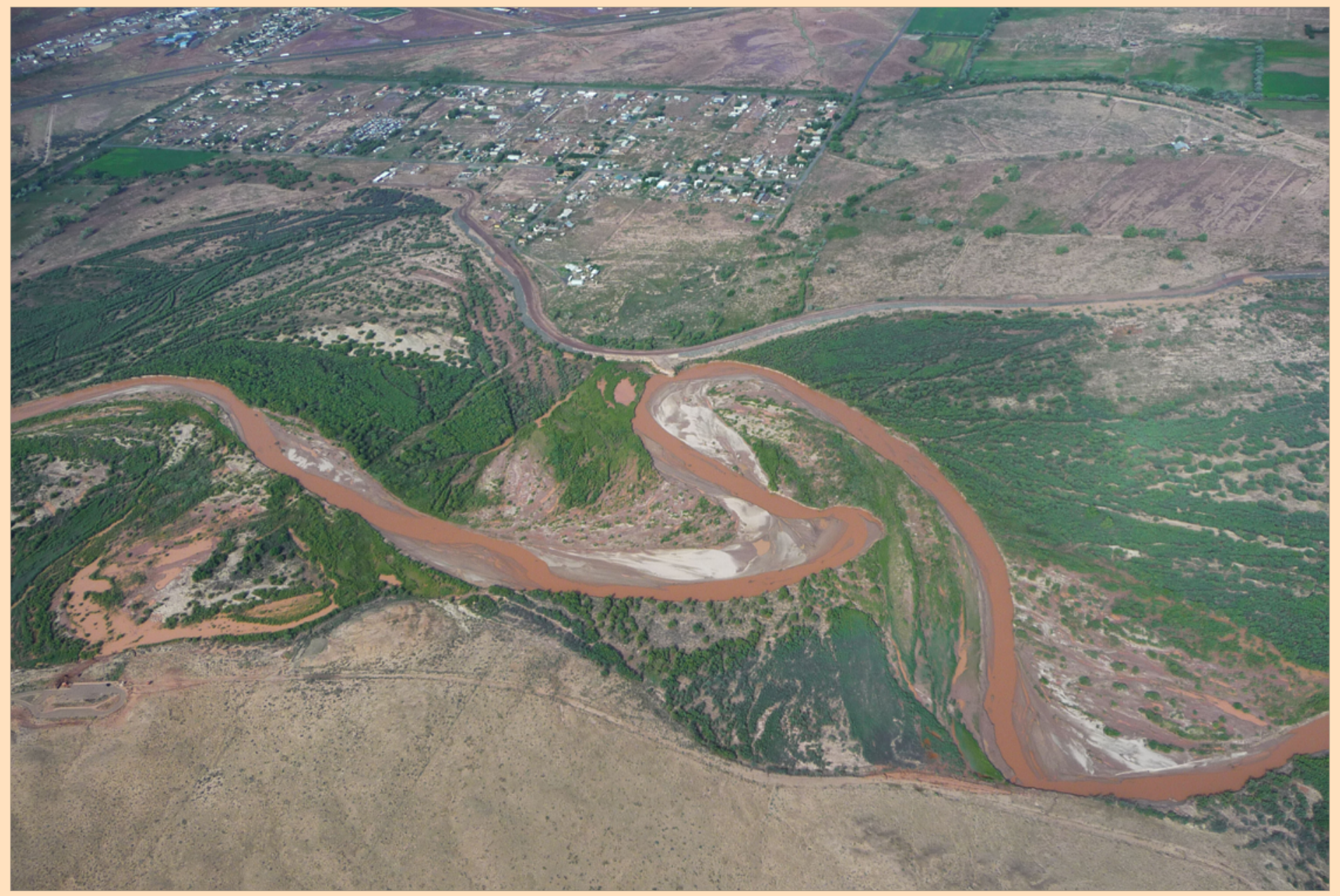

Scientific Investigations Report 2014-5112 
FRONT COVER

The Little Colorado River between Homolovi State Park and Winslow, Ariz., August 3, 2013. View westward; photograph by Jon Mason, U.S. Geological Survey. 


\section{Historical Channel-Planform Change of the Little Colorado River near Winslow, Arizona}

By Debra Block

Prepared in cooperation with the Navajo Nation

Scientific Investigations Report 2014-5112 


\title{
U.S. Department of the Interior SALLY JEWELL, Secretary
}

\section{U.S. Geological Survey Suzette M. Kimball, Acting Director}

\author{
U.S. Geological Survey, Reston, Virginia: 2014
}

For more information on the USGS - the Federal source for science about the Earth, its natural and living resources, natural hazards, and the environment-visit http://www.usgs.gov or call 1-888-ASK-USGS

For an overview of USGS information products, including maps, imagery, and publications, visit http://www.usgs.gov/pubprod

To order this and other USGS information products, visit http://store.usgs.gov

Suggested citation:

Block, Debra, 2014, Historical channel-planform change of the Little Colorado River near Winslow, Arizona: U.S. Geological Survey Scientific Investigations Report 2014-5112, 24 p., 2 plates, http://dx.doi.org/10.3133/ sir20145112.

ISSN 2328-0328 (online)

Any use of trade, firm, or product names is for descriptive purposes only and does not imply endorsement by the U.S. Government.

Although this information product, for the most part, is in the public domain, it also may contain copyrighted materials as noted in the text. Permission to reproduce copyrighted items must be secured from the copyright owner. 


\section{Acknowledgments}

This study was conducted with the permission of the Navajo Nation Department of Minerals, the Navajo Nation Water Management Branch, and the Leupp and Birdsprings Chapters of the Navajo Nation. Access to the Winslow levee was granted by Trent Larson of Navajo County. The staff of Homolovi State Park graciously allowed access to the river channel adjacent to the park. Tammy Rittenour of the Utah State University's Luminescence Laboratory analyzed the optically stimulated luminescence signals from late Pleistocene terraces adjacent to the study area (fig. 1). Michael Marshall, of the USGS, provided guidance on the use of the R statistical software. Colleagues in the USGS Arizona Water Science Center, particularly Dave Anning, Don Bills, Brad Garner, Nancy Hornewer, Jamie Macy, and Jon Mason, contributed their data and expertise in numerous invaluable discussions. I thank Kyle House, Paul Grams, Chuck Powell, and Margaret Hiza Redsteer of the USGS for their detailed and helpful reviews of the manuscript, and Joel Pederson, of the Utah State University, for his additional technical review. 


\section{Contents}

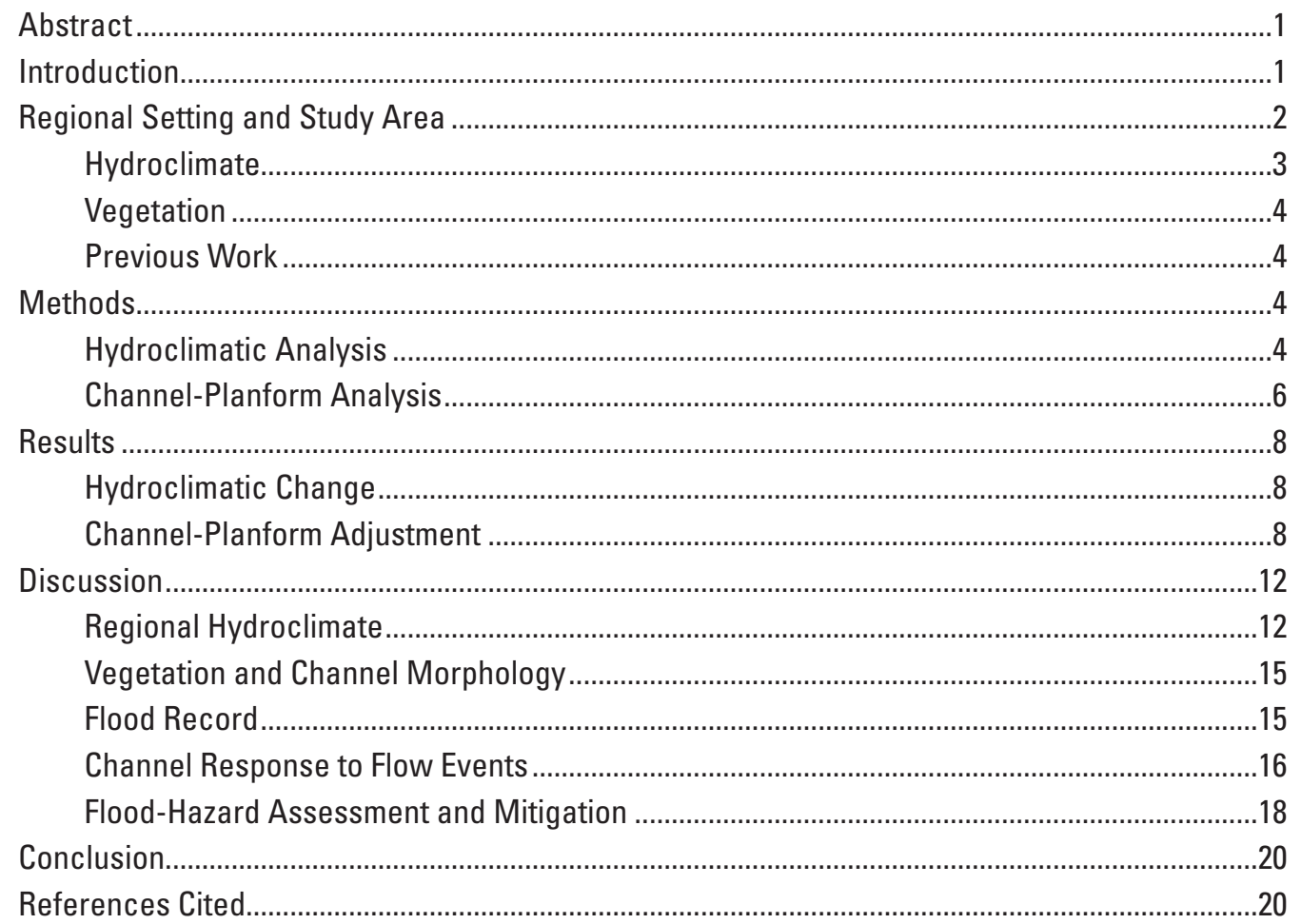




\section{Figures}

1. Map of the Little Colorado River Basin, Arizona ......................................................................

2. Hydrographs for streamflow-gaging stations on the Little Colorado River ................................5

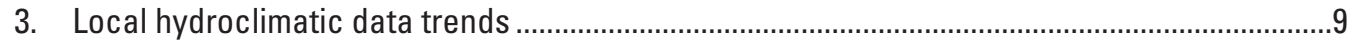

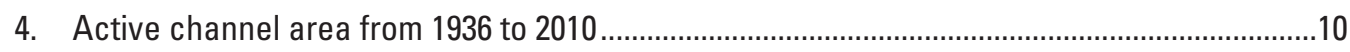

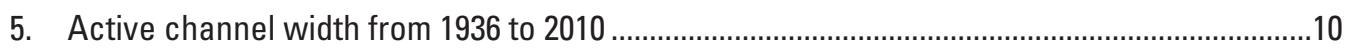

6. Channel centerline migration distances and annualized migration rates................................11

7. Cumulative centerline migration versus distance along Little Colorado River near

Winslow, Ariz

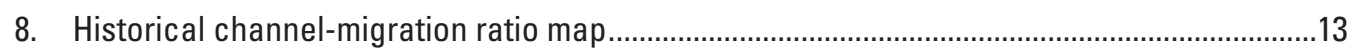

9. Aerial photographs showing sinuosity of avulsion zones ...................................................14

10. Photographs of active meander bend on the Little Colorado River near Winslow, Ariz..........15

11. Hydrographs for flood events at two streamflow-gaging stations on the Little Colorado

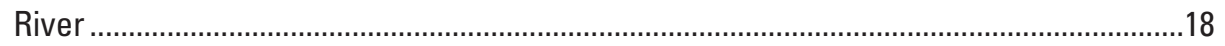

12. Aerial photographs showing geomorphologic changes and human modifications to the

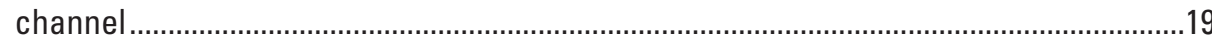

\section{Tables}

1. Aerial photographs used in channel analysis of Little Colorado River near Winslow, Ariz......7

2. Comparison of aerial photography record with flood record on the Little Colorado River near Winslow, Ariz.

\section{Plates}

[Available online only at http://pubs.usgs.gov/sir/2014/5112/.]

1. Historical Channel-Planform Change Map of the Little Colorado River near Winslow, Arizona.

2. Map of Channel Migration Distance on the Little Colorado River between Winslow and Leupp, Arizona. 



\title{
Historical Channel-Planform Change of the Little Colorado River near Winslow, Arizona
}

\author{
By Debra Block
}

\section{Abstract}

This study evaluates channel-planform adjustment on an alluvial reach of the Little Colorado River and documents the geomorphic evolution of the channel through an analysis of aerial photographs and orthophotographs for the period 1936-2010. The Little Colorado River has adjusted to the effects of an extreme flood in 1923 and a subsequent decline in peak discharge and mean annual flow by channel narrowing: the channel width and area of the river have decreased by approximately 90 percent over the study period. Although deposition historically exceeds erosion, lateral migration exacerbates localized erosion, particularly near hydraulic controls. Despite repeated cutoff and avulsion, the Little Colorado River has steadily increased in length and sinuosity over a period of 74 years.

Changes in temperature and precipitation are likely affecting the discharge of the Little Colorado River near and downstream of Winslow, Ariz. Nonparametric methods of trend detection determine whether the probability distribution of temperature, precipitation, and peak streamflow has changed over time. Time-series plots of temperature and precipitation show statistically significant trends at the 99-percent-confidence level when evaluated with a Mann-Kendall test. An increasing trend was indicated in mean daily minimum air temperature $\left(T_{\min }\right)$, whereas decreasing trends were indicated in both annual precipitation $\left(P_{\text {ann }}\right)$ and monsoon-seasonal precipitation $\left(P_{\text {jas }}\right)$, as well as in peak discharge.

\section{Introduction}

Fluvial processes in dryland regions differ substantially from those in humid temperate regions (Graf, 1988), primarily with regard to when and how streamflow occurs. Whereas arid- or semiarid-zone rivers are typically intermittent and ephemeral or have erratic flow regimes, humid-zone rivers are mostly perennial. In drylands, fluvial processes are driven by precipitation. Because precipitation and runoff are extremely variable in drylands, both temporally and spatially, river behavior also is characteristically inconstant. In fact, the hydrologic variability in North American drylands, as defined by the coefficient of variation of annual streamflow, is about twice that of the entire North American Continent
(McMahon, 1979). Thus, the frequency distribution of discharge in dryland rivers is unlike that in humid rivers (Bull and Kirkby, 2002).

Flood-plain management of meandering dryland rivers like the Little Colorado presently relies on flood-frequency analyses, which incorporate an assumption of stationarity. Yet this assumption, under which system variables (for example, annual streamflow) are statistically time invariant, is invalidated by the hydrologic variability intrinsic to drylands (Webb and Betancourt, 1992). Mixed populations of flood-generating storms further complicate flood-frequency analyses along dryland rivers (Dunne and Leopold, 1978), and additional complexities result from changing climatic trends in the Western United States (Barnett and others, 2008). Indeed, the current magnitude and ubiquity of hydroclimatic change undermines any assumption of stationarity for water management globally (Milly and others, 2008).

In contrast, this study presents an evaluation of the geomorphic response to changing hydroclimatic conditions. Historical channel-planform change provides a context for flood-plain-management planning. Such change is measurable on channel polygons mapped from aerial photography in a geographic information system (GIS). Channel-planform adjustment is a vital component of management-relevant landscape change in dryland fluvial environments.

This study documents the channel-planform change of the Little Colorado River between the city of Winslow, Ariz., and the Navajo Nation community of Leupp (fig. 1), using mapping and GIS analysis of aerial photography acquired between 1936 and 2010. Repeat mapping indicates a neartenfold reduction in two-dimensional channel area and a comparable decrease in average channel width over a period of 74 years. Channel narrowing has commonly been ascribed to changes in vegetation or hydrology. Riparian vegetation does influence flow hydraulics and, therefore, morphology by increasing the coefficient of roughness, thereby inducing sediment deposition (Thorne, 1990). Yet where cutbank heights are greater than rooting depths, roots are largely ineffective in preventing lateral bank erosion, and thus may not be a factor in channel narrowing (Jacobson and Pugh, 1998). Channel narrowing has also been attributed to reduced peak flows, whether controlled by impoundment, diversion, groundwater withdrawal, or climate (for example, Bradley and Smith, 1984; Wohl and others, 2009; Ollero, 2010; Cadol and others, 2011; Dean and Schmidt, 2011; Perşoiu and Rădoane, 2011). Reductions in discharge on the study reach of the Little Colorado 
River (fig. 1) are explainable by changes in temperature and precipitation. Localized hydroclimatic trends are statistically significant and suggest decreasing water availability as a driver in channel narrowing.

The purposes of the present work are (1) to present repeat measurements of channel morphology from aerial photography, (2) to broadly assess the effect of riparian vegetation on local channelflow, (3) to evaluate previous assessments of channel stability, and (4) to augment knowledge of climatic influence on the geomorphology of the Little Colorado River near Winslow, Ariz. (fig. 1). This study adds to understanding of the potential responses of dryland fluvial systems under duress from water scarcity and projected hydrologic variability.

\section{Regional Setting and Study Area}

The Little Colorado River is a major northwest-flowing tributary of the Colorado River in northeastern Arizona, with headwaters originating in the White Mountain volcanic field of east-central Arizona (fig. 1). The river course is $\sim 565 \mathrm{~km}$ long, with a descent of $>2 \mathrm{~km}$ in elevation. In the $\sim 90-\mathrm{km}$ study reach between Winslow and Leupp, the Little Colorado River valley approximately parallels the regional strike of the sedimentary Mesozoic strata that the river has eroded. Its broad valley cuts across the Triassic Moenkopi and Chinle Formations, which are covered by extensive alluvial and eolian deposits (Billingsley and others, 2013). Clay, silt, and fine-tomedium-grained sand dominate the channel banks and bed in the study reach of the river. Banks are steep, and relief varies on the channel bed. Parts of the channel contain multiple thalwegs. Bedrock strata of the Moenkopi Formation crop out sporadically in the channel bed near Leupp and infrequently along the right bank near Winslow.

Chevelon and Clear Creeks are perennial tributaries that flow northeasterly toward their confluences with the Little Colorado River above Winslow (fig. 1). These tributaries drain the highly fractured sandstone bedrock highlands to the southwest of the Little Colorado River flood plain. Minor spring

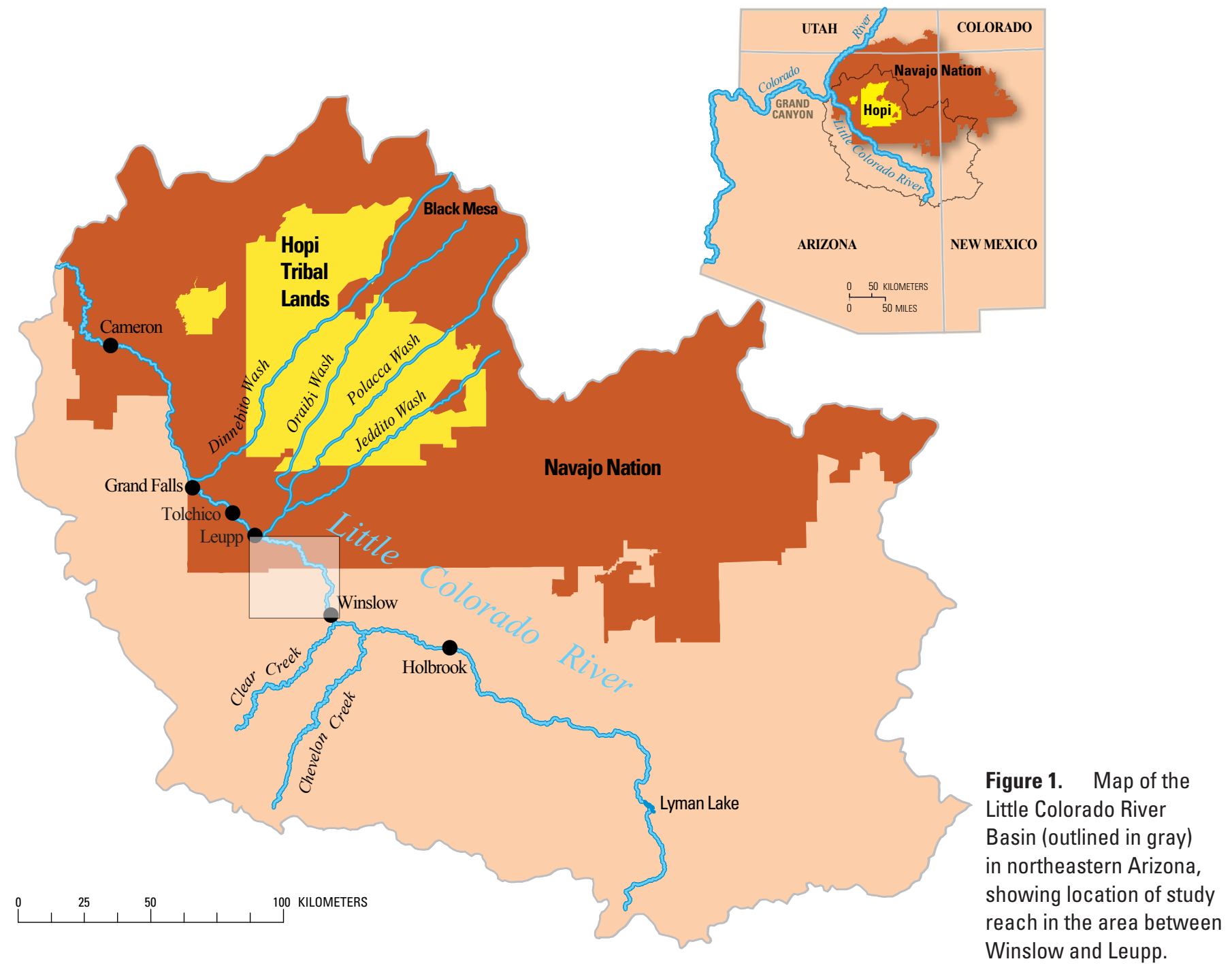


and seep inflow rises from bedrock fractures in the channel between the input of the two creeks. An artesian spring in Clear Creek contributes to a base flow of 4 to $5 \mathrm{ft}^{3} / \mathrm{s}$ near Winslow (Don Bills, written commun., 2011), which diminishes rapidly downstream, where flow depends on runoff from rainfall and snowmelt. Tributaries northeast of the study area, the ephemeral Tusayan Washes-Dinnebito, Oraibi, Polacca, and Jeddito - dissect and drain mesas that step downward to the west, carrying monsoon flow during the summer months.

The Little Colorado River watershed drains an area of $\sim 70,000 \mathrm{~km}^{2}$ that comprises 18 subbasins (see http://water. usgs.gov/osw/streamstats/). Although the river is ephemeral or intermittent along most of its course, perennial reaches occur at the headwaters and for $21 \mathrm{~km}$ above the mouth, where the river is spring fed. The Little Colorado River was perennial above Holbrook in the early 1930s (Harrell and Eckel, 1939) and above Winslow in the 1910s (Gregory, 1916). Flow is partly regulated downstream of Lyman Lake, an irrigation storage reservoir near the headwaters that is maintained by snowmelt, for $\sim 30 \mathrm{~km}$. Below that point, groundwater discharge is affected by withdrawal from the $\mathrm{C}$ aquifer, (Cooley and others, 1969), named for the primary water-bearing unit within the aquifer, the Coconino Sandstone, which underlies the entire surface-water drainage of the Little Colorado River (Hart and others, 2002). Groundwater discharge from the $\mathrm{C}$ aquifer is the source of base flow for parts of the Little Colorado River and for Chevelon and Clear Creeks.

Groundwater development in the Little Colorado River Basin was negligible before the 1940s (Hart and others, 2002). Since then, pumping, as well as episodes of sustained drought, has caused groundwater levels to decline, although the effects have been localized mostly near industrial sites in the southcentral part of the basin (Hart and others, 2002). Pool and others (2010) constructed a numerical flow model to evaluate the hydrologic effects of groundwater withdrawal on regional groundwater-flow systems. The observed predevelopment (pre-1938) hydraulic head at 129 wells that tap the $\mathrm{C}$ aquifer was comparable to simulated steady-state water-level altitudes during development (1938-2006). Simulated variations in groundwater discharge could not be evaluated against observations, owing to insufficient long-term gage records. Simulated groundwater budgets for the Little Colorado River Basin near Winslow, however, indicate that historical changes are dominated by variations in recharge rates, not by withdrawals (Pool and others, 2010). Possible future effects of groundwater withdrawal on base flow derived from groundwater discharge near Winslow are indeterminate, as are natural variations in recharge. A recent monitoring study on Chevelon and Clear Creeks was too brief to observe base-flow trends in these tributaries (Brown and Macy, 2012).

\section{Hydroclimate}

Whereas climate change is a substantial and inexorable alteration of a region's average climatic conditions-temperature and precipitation patterns-or the extremes of these patterns, climate variability represents differences in global weather systems occurring over periods of years to decades (Hansen and others, 2006). Global patterns of atmospheric flow drive oceanic-circulation patterns; general atmospheric and oceanic circulations generate weather patterns that uniquely characterize regional climates. Regional precipitation is distinctly bimodal and has been described in many reports (for example, Hereford and others, 2002; Webb and others, 2004). During the warm season, precipitation occurs as the North American Monsoon (NAM) brings in moisture from the east Pacific Ocean and the Gulf of California, initiating convective thunderstorms (Adams and Comrie, 1997). The NAM is characterized by a pronounced increase in rainfall beginning in July and lasting through September. Monsoon rainfall is locally concentrated; a 10-km-wide convective storm cell has an areal extent of only $100 \mathrm{~km}^{2}$ at any one time, and a lifespan of only several minutes to hours (Hirschboeck, 1988). Although intense monsoonal rainstorms over sparsely vegetated ground may generate locally high rates of overland flow, runoff is generally patchy, and few storms produce significant channel flow. In contrast, cool-season precipitation (Oct. 16-Apr. 15; see Hereford and others, 2002) typically results from early-fall tropical cyclones and winter low-pressure-frontal systems (for example, Webb and Betancourt, 1992). These storms are associated with anomalous atmospheric-circulation patterns, can affect an area of $10^{6} \mathrm{~km}^{2}$, and have a characteristic lifespan of 3-6 days (Hirschboeck, 1988). Most flooding on the Little Colorado River occurs during the cool season.

Generally, the spatial and temporal variability in precipitation directly affects hydrologic response in semiarid regions. High rates of evaporation and transmission loss result in disconnected drainage networks in which the flow produced from runoff is spatially discontinuous or decreases downstream. Results from a study of a densely gaged experimental watershed in southeastern Arizona indicate that significant differences in rainfall totals over short distances are reflected in a rapidly decreasing correlation of streamgage pairs with increasing distance between gages (Osborn and others, 1979). Large uncertainties in runoff estimation can result from even small-scale spatial differences in rainfall (Faurès and others, 1995). Thus, broadly interpolated data from the sparsely gaged watershed of the Little Colorado River is inadequate to model runoff response there.

Goodrich and others (1997) observed that as semiarid watershed scale increases, runoff response becomes even more nonlinear because of the increasing importance of ephemeral channel losses and partial storm-area coverage. Runoff volume markedly diminishes as the flood hydrograph progresses downstream between the streamflow-gaging stations near Winslow and Cameron on the Little Colorado River, a distance of $\sim 170 \mathrm{~km}$. Losses from the flood hydrograph through infiltration resulted in a downstream reduction in flow volume of $14,580 \mathrm{ft}^{3}$ for a single winter-storm event, a transmission loss of 38 percent between the streamflow gages (Block and Redsteer, 2011), confirming that even synoptic storms of greater 
Historical Channel-Planform Change of the Little Colorado River near Winslow, Arizona

areal extent than monsoons produce disparate flood hydrographs in the Little Colorado River Basin.

\section{Vegetation}

Flood-plain vegetation in the study area (fig. 1) has changed strikingly over the historical record. The first written observations of the Little Colorado River were by $16^{\text {th- }}$ century Spanish explorers, who described "a fine, beautiful, and selected river almost as large as the Del Norte [Rio Grande], containing many groves of poplars [cottonwoods] and willows" (Luxan, 1583). When Capt. Lorenzo Sitgreaves explored the area in 1851, his party encountered extensive and often-impassable swamplands above Winslow (Sitgreaves, 1853). Two years later, A.W. Whipple's expedition followed a parallel course. At the junction of Diablo Canyon (near Leupp), Whipple (1856) wrote of thick groves of cottonwoods. He also remarked upon the river in the vicinity of Winslow as a "net-work of channels, all bordered with alamos [cottonwoods]" (p. 76).

By the 1930s, most native vegetation had disappeared: "The willows have departed, and only a few gnarled cottonwoods remain of the once-extensive groves. The surrounding hills that once bore a good stand of grama grass are now covered with a desert pavement of polished pebbles" (Colton, 1937). In the 1930s, tamarisk, a native shrub of Eurasia, began to noticeably colonize the southwestern flood plains (Robinson, 1965). Although no systematic comparison of vegetation was made in this study, the spread of tamarisk on the Little Colorado River flood plain is chronicled through aerial photography. Historical meander scars were rapidly colonized by tamarisk. Currently, willows are supplanting tamarisk on aggrading channel reaches in the study area (fig. 1).

\section{Previous Work}

Hack (1942) applied the theory of climatic terraces to the valleys of western Navajo and Hopi country. He divided the alluvium of the Tusayan Washes, from Black Mesa to the Little Colorado River (fig. 1), into three periods of deposition, each preceded by a period of accelerated erosion. The alternating periods of deposition and erosion, Hack argued, resulted from minor changes in stream gradient, which, in turn, resulted from climatic change. During periods of deposition the grade was flattened and climatic conditions were wetter; during periods of erosion the grade was steepened and climatic conditions were drier. Hack further suggested that the "epicycles of erosion" were regionally contemporaneous.

Hereford (1984) analyzed the influence of climate on the geomorphology and alluvial stratigraphy of the Little Colorado River in narrow bedrock-canyon reaches from Tolchico to Cameron. A time-stratigraphic analysis showed synchronous deposition throughout his study area, which supports, as Hack (1942) posited, regional climatic control over sedimentation. In contrast to Hack, Hereford determined that erosion occurred under wet conditions and alluviation occurred under dry conditions. Moreover, Hereford emphasized a climatic association with the mode of flood-plain construction until a geomorphic threshold, the elevation of the flood plain, was reached - the same process that Wolman and Leopold (1957) described in their treatise on flood-plain formation - whereby the flood-plain surface can become a terrace only by tectonic or climatic change that alters the regimen of the river. Hereford suggested that overbank or vertical accretion was succeeded by within-channel or lateral accretion in 1980, when a threshold flood-plain elevation was reached and high flows no longer overtopped channel banks.

Huckleberry (1996) mapped surficial deposits along the leveed reach of the Little Colorado River at Winslow as a means to assess the recent aggradational history of the area, with implications for a levee breach that had occurred in 1993. He concluded that overall, aggradation was negligible in the leveed reach in the recent past ( 1975-95), and noted that aggradation was spatially limited by the elevation of alluvial deposits and by distance from the main channel. He also determined that the older deposits were stabilized sufficiently by vegetation and would resist erosion other than by "extraordinary flood events."All of his mapped alluvial surfaces were deposited within the historical record.

The Bureau of Reclamation (2003) conducted a geomorphic analysis, complemented by hydraulic and sediment-transport modeling, of the Little Colorado River between Holbrook and Winslow (fig. 1), including the leveed reach. Using an assumed channel-forming flow rate of $5000 \mathrm{ft}^{3} / \mathrm{s}$, they calculated stable channel geometries for various suspendedsediment concentrations and concluded that the geometry of the river is well characterized by their model and thus that the river is currently (2003) in a slightly degraded, but stable, condition. They defined "stability" solely as the equivalence of the river's transport capacity to the incoming sediment load. The general conclusion of their study is that future sediment aggradation will be insignificant.

\section{Methods}

\section{Hydroclimatic Analysis}

U.S. Geological Survey (USGS) streamflow-gaging stations on the Little Colorado River and its tributaries have provided discharge data intermittently since 1905 . The streamflow data used in this report are from the following main-stem gages on the Little Colorado River: at Grand Falls (09401000), near Cameron (09402000), and near Winslow (09400350) (fig. 2). The period of record for the gage at Grand Falls began in November 1925; daily discharge data were recorded through 1949 and intermittently between 1950 and 1995, after which the gage was discontinued. The gage near Cameron has been in continual operation since June 1947, and the gage near 


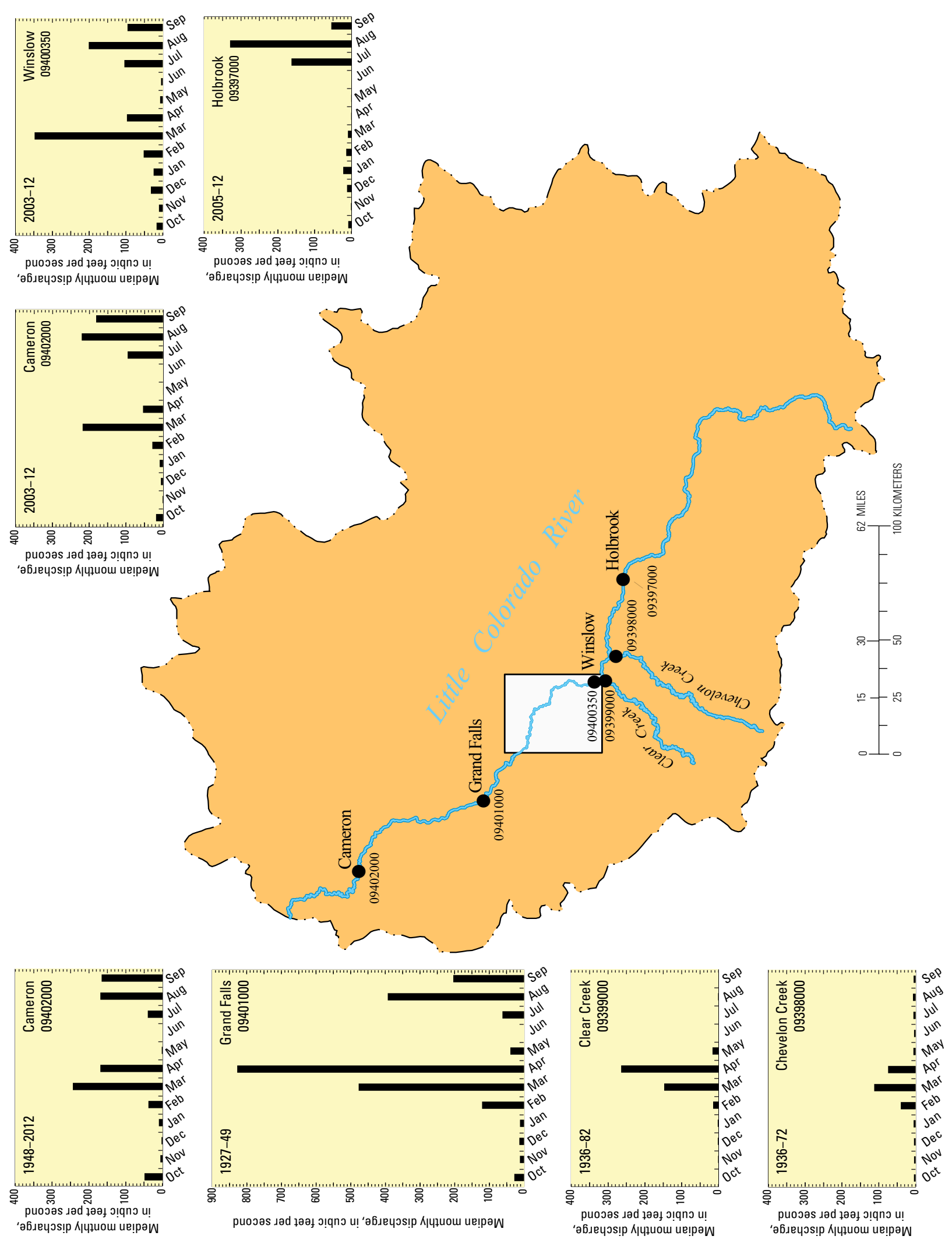


Winslow began recording data in December 2001. Aside from the one near Winslow, the main-stem gage nearest the study reach (fig. 1) is at Holbrook (09397000), $\sim 55 \mathrm{~km}$ upstream of the study area. Data from this gage, however, show a seasonal discharge pattern that differs from those at the downstream gages, and so are not a good proxy for the discharge downstream (fig. 2). Discharge data from streamflow-gaging stations on two tributaries to the Little Colorado River were also used in this report: on Clear Creek near Winslow (09399000) and on Chevelon Creek near Winslow (09398000) (fig. 2), both of which were in operation for varying periods of record beginning in 1905 but have since been discontinued.

Because the discharge record for the streamflow-gaging station near Winslow is brief, and interstation runoff volumes are not directly correlative, an analysis of local temperature and precipitation was undertaken to test for hydroclimatic trends, using observations collected over a period of 98 years at a meteorological station in Winslow. Hydroclimatic data were analyzed by using the RStudio software, with $R$ functions from the packages "Kendall" and "zyp." A nonparametric Mann-Kendall test allows for departures from normal distribution and is based on rank correlation (Helsel and Hirsch, 2002). Kendall's rank-correlation coefficient $\tau$ is used to test for any monotonic dependence of $Y$ (temperature, precipitation, and discharge) on $X$ (time). Kendall's coefficient signifies the correlation, or strength of association, between two continuous variables and is resistant to the effect of outliers. For time-series data, the significance of this correlation is that it indicates the probability that the trend differs from the mean. The hypothesis that $Y$ depends on $X$ is confirmed by two-sided $p$-values $<0.01$, indicating a statistically significant correlation in the data. Thus, the null hypothesis of no trend can be rejected. The statistical significance of trends in the time-series data was confirmed by a Mann-Kendall test at the 99-percentconfidence level.

Monotonic trends in the hydroclimatic data are shown by the nonparametric Thiel-Sen slope, which indicates the direction and magnitude of change and so is used to determine the rate of change. The data-smoothing technique LOWESS (locally weighted scatterplot smoothing) shows local variations in trend direction and slope (Helsel and Hirsch, 2002). The LOWESS line is therefore a reflection of the pattern of dependence of $Y$ on $X$, rather than a fit of a straight line through the data.

\section{Channel-Planform Analysis}

Morphologic change of an alluvial reach of the Little Colorado River (fig. 1) is documented by repeat digital mapping from aerial photography acquired in 1936, 1953, 1979-1980, 1992, 1997, 2007, and 2010 (pl. 1; table 1). Aerial photographs from 1936, 1953, 1979-80, and 1992 were scanned at a resolution of 1,200 dots per inch (dpi) and georectified in ArcGIS. Ground-control points (GCPs) for georeferencing were identified and linked at 1:5,000 scale. Aerial photographs from 1997, 2007, and 2010 were acquired as digital orthophotos, corrected for camera-tilt and terrain-relief distortion, with a $1-\mathrm{m}$ ground sample distance (GSD). The 1997 digital orthophoto quadrangles (DOQs) were used as the base or reference layer for all georeferenced imagery. The GSD of each digital aerial photograph, calculated from the original photographic scale and the scanning resolution, is less than the 1-m GSD of the DOQ to which it was georeferenced.

The number and distribution of GCPs used for georectification varied; from 10 to 35 GCPs were used on each scanned aerial photograph for georectification to the 1997 DOQs. The GCPs used are overwhelmingly soft edged and near to the ground because the study area (fig. 1) is a largely undeveloped, minimally vegetated, low-relief flood plain. Because many of the features used as GCPs were eradicated by subsequent landscape change, GCPs could not be standardized and some of the images required coregistration to previously georectified images. The GCPs selected in this study are also concentrated near the river channel rather than distributed throughout the image, to minimize distortion in the area of interest.

A second-order-polynomial transformation with a least-squares-fitting algorithm was used for spatial registration. Residual errors generated by the transformation are the distance between the transformed location of the GCP and the actual map-coordinate $(x, y)$ location. The aggregate error for each image is the square root of the mean of squares of the residuals for each GCP and map-coordinate pair. Registration-error margins for georeferenced imagery depend on the original photographic scale and quality. The root-meansquare (rms) errors for each georeferenced dataset are listed by range $(0.35-7.53 \mathrm{~m})$ and average $(0.65-5.0 \mathrm{~m})$ in table 1 . Accuracy specifications for the orthorectified data are noted by the contracting agency, as indicated in table 1 .

Mount and others (2003) demonstrated that image orthorectification provides little improvement in spatial accuracy over second-order-polynomial transformation for digital imagery of low-relief flood plains. Furthermore, Neteler and Mitasova (2004) determined that when the elevation range of the study area does not exceed 1/500 of the image scale, distortion due to topographic relief is negligible for nonorthorectified imagery. The topography of the study area (fig. 1) fits these conditions.

Georectification accuracy also is not appreciably affected by the absolute number of GCPs above a threshold, nor by the use of soft-edged points, such as isolated tree canopies (Hughes and others, 2006). Greater spatial density of GCPs within an area of interest, however, can improve accuracy, owing to a superior fit to local topography (Hughes and others, 2006). Although concentrating GCPs along a river channel can improve locational accuracy, that improvement may not be reflected in the rms error. Because error is not distributed uniformly, the rms error is simply a measure of the magnitude of a varying quantity; rms values do not capture the spatial variations in error (Unwin, 1995). 
Table 1. Aerial photographs used in channel analysis of Little Colorado River near Winslow, Ariz.

[Total positional error calculated as the square root of the sum of the squares of the source registration error (1.2 m), the transformation registration error, and an assumed digitizing error $(3 \mathrm{~m})^{1}$. For digitally orthorectifed photographs (1997), range of root-mean-square (rms) error is from the imagery header. For digitally orthorectified photographs (2007 and 2010), average rms error is the error stated by the U.S. Department of Agriculture (USDA); for 2007 photographs error is the accuracy specifications maximum; for 2010 photographs error is regional registration maximum from Geospatial Services Branch of the USDA.]

\begin{tabular}{|c|c|c|c|c|c|c|c|c|}
\hline Year & $\begin{array}{c}\text { Photograph } \\
\text { date }\end{array}$ & Roll or quadrant & Source & Scale & $\begin{array}{l}\text { Range of } \\
\text { root-mean- } \\
\text { square } \\
\text { error } \\
\text { (m) }\end{array}$ & $\begin{array}{l}\text { Average } \\
\text { root-mean- } \\
\text { square } \\
\text { error } \\
\text { (m) }\end{array}$ & $\begin{array}{l}\text { Transform } \\
\text { error }+ \\
\text { source error } \\
\text { (m) }\end{array}$ & $\begin{array}{l}\text { Total } \\
\text { positional } \\
\text { error } \\
\text { (m) }\end{array}$ \\
\hline 1936 & $10 / 9 / 1936$ & -- & $\begin{array}{l}\text { Soil Conservation } \\
\text { Service }\end{array}$ & $1: 62,500$ & $1.38-7.53$ & 4.42 & 5.62 & 6.4 \\
\hline $1979-80$ & $\begin{array}{l}8 / 22 / 1979 \\
10 / 3 / 1980\end{array}$ & -- & U.S. Geological Survey & $\begin{array}{l}1: 24,000 \\
1: 30,000\end{array}$ & $\begin{array}{l}0.21-0.97 \\
0.62-1.25\end{array}$ & $\begin{array}{l}0.65 \\
0.95\end{array}$ & $\begin{array}{l}1.85 \\
2.15\end{array}$ & $\begin{array}{l}3.5 \\
3.7\end{array}$ \\
\hline 1992 & $\begin{array}{l}4 / 28 / 1992 \\
4 / 28 / 1992 \\
9 / 22 / 1992\end{array}$ & $\begin{array}{l}5144 \\
5225 \\
5240\end{array}$ & $\begin{array}{l}\text { U.S. Geological Survey } \\
\text { National Aerial } \\
\text { Photography } \\
\text { Program }\end{array}$ & $1: 40,000$ & $0.37-1.71$ & 0.94 & 2.14 & 3.7 \\
\hline 1997 & $\begin{array}{l}6 / 22 / 1997 \\
6 / 26 / 1997 \\
6 / 27 / 1997 \\
10 / 16 / 1997\end{array}$ & $\begin{array}{l}9828 \\
9834 \\
9836 \\
9845\end{array}$ & $\begin{array}{l}\text { U.S. Geological Survey } \\
\text { National Aerial } \\
\text { Photography } \\
\text { Program }\end{array}$ & $\begin{array}{l}1 \mathrm{~m} \mathrm{GSD} \\
\text { (ground } \\
\text { sample } \\
\text { distance) }\end{array}$ & $0.55-2.50$ & 1.20 & -- & 3.2 \\
\hline 2007 & $\begin{array}{l}6 / 7 / 2007 \\
6 / 18 / 2007 \\
6 / 19 / 2007 \\
6 / 07 / 2007 \\
6 / 19 / 2007 \\
6 / 07 / 2007 \\
6 / 07 / 2007\end{array}$ & $\begin{array}{l}3511041 \\
3511042 \mathrm{SW} \\
3511042 \mathrm{SE} \\
3511050 \mathrm{SW} \\
3511050 \mathrm{NW} \\
3511051 \\
3511059\end{array}$ & $\begin{array}{l}\text { U.S. Department of } \\
\text { Agriculture } \\
\text { National Agriculture } \\
\text { Imagery Program }\end{array}$ & $1 \mathrm{~m} \mathrm{GSD}$ & -- & 5.00 & -- & 5.8 \\
\hline
\end{tabular}

${ }^{1}$ Method follows Hapke and Reid (2007)

Additional error is introduced during digitization of channel boundaries. To assess this error, Downward and others (1994) constructed a simple test of redigitizing the same channel boundary position 50 times and looked at the frequency distribution of line displacement. By analyzing the variation in digitizing error, they established a value for channel-boundary disagreement required to identify actual channel movement in their data. Their investigation established that the validity of quantified change requires that the sum of inherent and introduced spatial error be lower than the amount of change measured. A 3-m digitizing error, based on buffer analysis in ArcGIS, is assumed for this study.

Total positional error for the change-detection margin on orthorectified imagery is calculated as the square root of the sum of squares of the averaged rms error and the digitizing error. Total positional error for the georeferenced imagery included an additional source-registration error of $1.2 \mathrm{~m}$ in the calculation, which is the average rms error for the base imagery (1997 DOQs) to which the scans were georeferenced (table 1).

During onscreen digitization of channel boundaries in this study, the active channel was defined where banks are clearly visible, or at abrupt linear changes in vegetation density that locally parallel the thalweg. On point bars with distinctly stepped profiles, the channel boundary is defined by the topographic break of the uppermost tier where the concentration of vegetation exceeds 10 percent by visual estimation. Channel boundaries are drawn to reflect ongoing geomorphic 
processes independent of flow conditions on the date of the aerial photograph, and so are an approximation of bankfull stage.

Channel centerlines were generated from Thiessen polygons defined by points located at 1-m intervals along the digitized channel banks and islands (see "ET GeoWizards function Build Thiessen Polygons," http://www.ian-ko.com/). Channel width was calculated at 20-m intervals, perpendicular to the centerline for each respective time slice. At meander bends where a centerline orthogonal projected parallel to streamflow direction, transects were adjusted to accommodate channel curvature. Average widths were calculated by dividing the channel area by the length of its centerline, and agree with the widths calculated by digital transect.

Channel-migration distances were calculated at 10-m intervals between successive centerlines (see "ET GeoWizards function Point Distance," http://www.ian-ko.com/). The ET GeoWizards tool measures the distance from points located at intervals on a centerline to the closest point along the subsequent channel centerline. Median centerline migration was calculated from the resulting distances. Distances were normalized as a percentage of the total distance to indicate relative degree of channel movement.

\section{Results}

\section{Hydroclimatic Change}

Median monthly hydrographs show seasonal discharge on the Little Colorado River in response to regional precipitation patterns (fig. 2). For the periods 1927-49 at Grand Falls and 1948-2012 near Cameron, the median of mean monthly discharge shows a bimodal distribution, with maximum discharge occurring during spring snowmelt and a second discharge peak occurring during the monsoon season (July-September). The shorter-term record near Winslow (2003-12) shows a comparable pattern, again with maximum discharge occurring during the months of snowmelt runoff.

Snowmelt runoff in the study reach of the Little Colorado River (fig. 1) is produced primarily through input from Clear and Chevelon Creeks, with $>600 \mathrm{~m}$ of relief between their headwaters and the confluences with the main stem. Runoff during February-May is $\sim 98$ percent of the total annual streamflow at Clear Creek for the continuous period of record (1936-82) at that gage, and $\sim 85$ percent of the total annual streamflow at Chevelon Creek for the continuous period of record (1936-72) at that gage.

For the main stem of the Little Colorado River, the earliest relevant record of continuous daily discharge measurements is from the streamflow-gaging station at Grand Falls (1927-49), where runoff was at a historical maximum during the month of April. During the continuous period of record, 67 percent of the total annual streamflow occurred during February-May at Grand Falls, more than half of which occurred in April. For the period of record of the streamflowgaging station near Cameron, which begins in 1948, 51 percent of total annual discharge occurs during February to May. When the discharge record of the gage near Cameron is examined for the period equivalent to the $21^{\text {st }}$-century discharge record of the gage near Winslow (2003-12), the percentage of discharge occurring during February-May has declined to 36 percent of the total annual discharge, with the greatest reduction occurring in April (fig. 2). Discharge records indicate changes in runoff timing that reflect earlier-onset snowmelt.

Peak-discharge measurements show declining trends at both the streamflow-gaging stations at Grand Falls and near Cameron (fig. 3). For the 34-year period of record (1926-59) of peak streamflow measurements from the gage at Grand Falls, and the 66-year record (1947-2012) of peak-streamflow measurements from the gage near Cameron, statistically significant downward trends occur in peak discharge at the rates of $-262.5 \mathrm{ft}^{3} / \mathrm{s}$ per year and $-72.5 \mathrm{ft}^{3} / \mathrm{s}$ per year, respectively.

Declines in peak discharge coincide with an increase in average daily minimum temperature and a decrease in annual precipitation (fig. 3). Monotonic trends in mean daily minimum air temperature $\left(T_{\min }\right)$, annual precipitation $\left(P_{\text {ann }}\right)$, and monsoon-seasonal (July-September) precipitation $\left(P_{\text {jas }}\right)$ are indicated by the nonparametric Thiel-Sen slope. The rate of change in $T_{\min }$ for the period $1915-2012$ is $+0.02^{\circ} \mathrm{F}$ annually, equivalent to an increase of $1.5^{\circ} \mathrm{F}$ over the 98 -year record of observation (fig. 3). The rate of change in precipitation for the period $1915-2012$ is $-0.513 \mathrm{~mm} / \mathrm{yr}$ for the annual time series and $-0.415 \mathrm{~mm} / \mathrm{yr}$ for the monsoon-season time series.

\section{Channel-Planform Adjustment}

The Little Colorado River meandered for $69 \mathrm{~km}$ between Winslow and Leupp in 1936, a straight-line distance of only $48 \mathrm{~km}$ (fig. 1). The river currently (2010) meanders for $91 \mathrm{~km}$ between the same two points. At the upstream end of the study reach, near the Interstate Highway 40 and railroad bridges at Winslow, the river has moved only marginally during the span of the aerial-photographic record. Engineering projects have restrained the channel since at least 1936 at Winslow, with periodic dredging. The channel also was largely stable for the study period at the downstream end of the study reach, northwest of Old Leupp, aside from a cutoff that occurred between 1936 and 1953 (pl. 2). There, the river flows in a strike valley of the very shallowly dipping Moenkopi Formation, which crops out directly southwest of the channel and in the riverbed beneath the Navajo Highway 15 bridge at Leupp. Yet overall, as the Little Colorado River migrated across its flood plain, it has become narrower, longer, and more sinuous.

Lateral migration and deposition of sediment resulted in increasing flood-plain construction over the historical record. As the Little Colorado River migrated laterally, the total active-channel area decreased progressively from 1936 to 

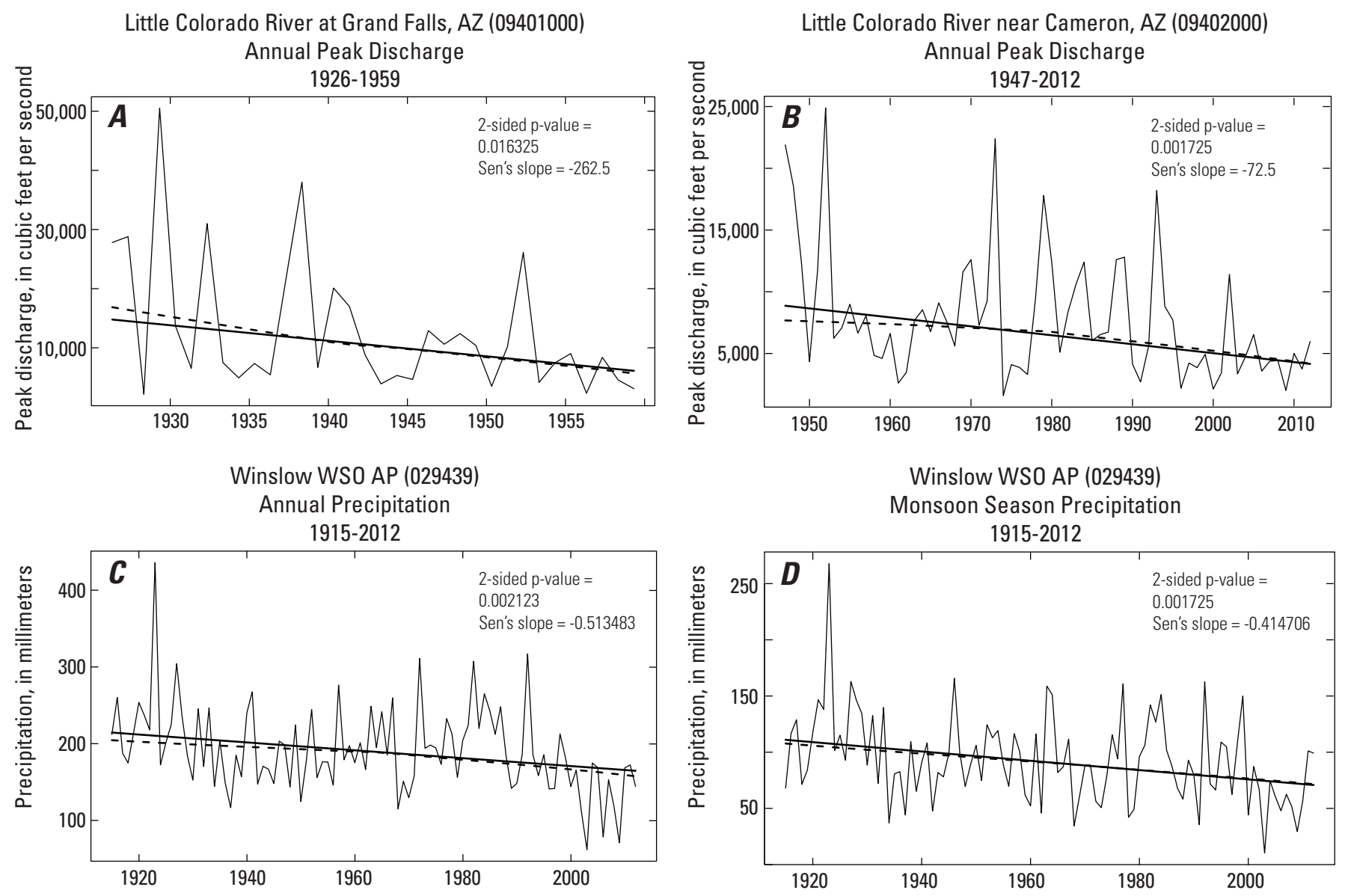

Winslow WSO AP (029439)

Yearly Average of Daily Minimum Temperature

1915-2012

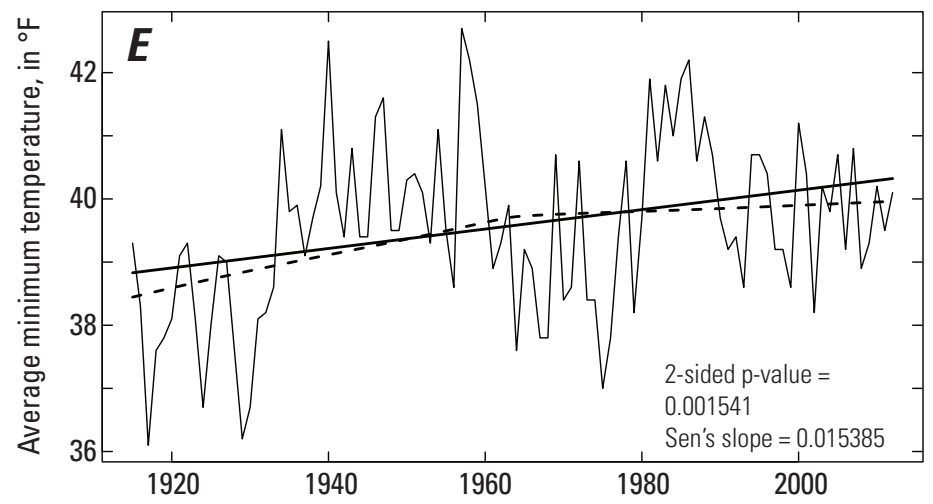

Figure 3. Monotonic trends in hydroclimatic data for the study area near Winslow, Ariz. (fig. 1). Solid line is Thiel-Sen slope; dashed line is LOWESS, which represents relation between variables as a nonlinear regression. $A$, Decline in peak discharge more rapid before 1940. $B$, Steady decline in peak discharge begins after 1973 flood. $C$, Greater decline in annual precipitation after 1980. $D$, Steady decline in monsoon-seasonal precipitation parallels Sen's slope. $E$, Steady increase in daily minimum temperature until 1960, when fluctuation in yearly average flattens trend. 
2010 (fig. 4). The river occupied $>26 \mathrm{~km}^{2}$ of surface area in 1936, when it flowed in a broad, largely unvegetated channel through the study reach from Winslow to Leupp. By 1953, more than half of the 1936 channel had been filled with sediment, while 35 percent of the active channel was newly eroded. By 2010, only $\sim 4$ percent of the active channel intersected the 1936 channel. The percentage of the 1936 channel that was occupied decreased as the surface area occupied by the river shrank. By 2010, the river occupied just $3 \mathrm{~km}^{2}$ of surface area and flowed through extensive stands of tamarisk.

Progressive channel narrowing has accompanied the process of lateral migration. Although the magnitude of the change in channel width varies throughout the study area (fig. 1) for each time interval, an overall decrease in average width,

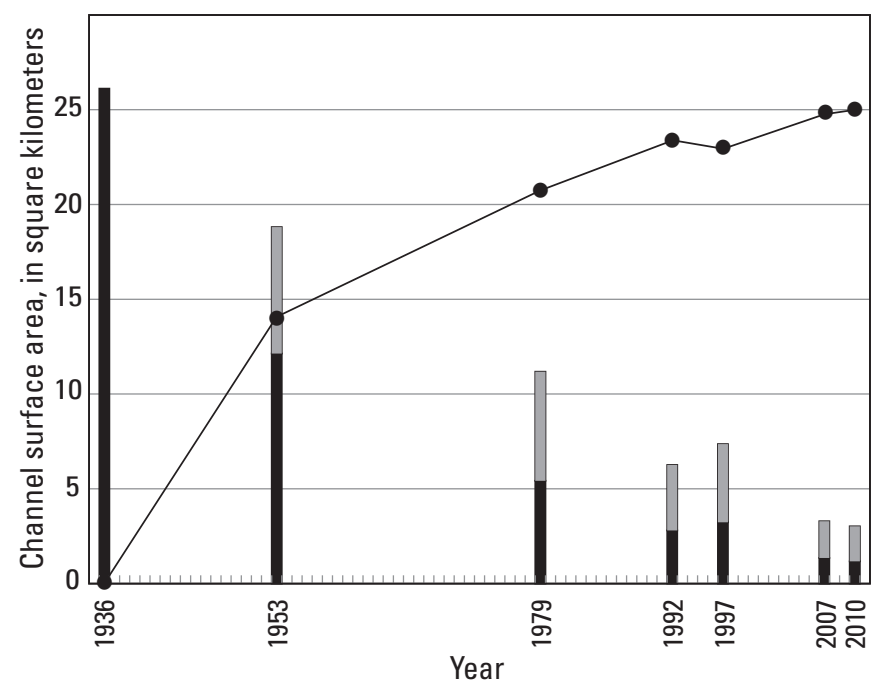

from $381 \mathrm{~m}$ in 1936 to $33 \mathrm{~m}$ in 2010, has occurred, a reduction of $>90$ percent (fig. 5). Over the study period, the progressive decrease in channel width reversed once, in 1997, in the aftermath of anomalous flood conditions that occurred in 1993. Despite a large flood in 2004, the river channel resumed narrowing, as indicated by width measurements from 2007

(fig. 5). Another significant flood occurred in 2008, when the lateral extent of overbank flow exceeded $3 \mathrm{~km}$, but the channel was still narrower in 2010 (fig. 5).

Median centerline migration correlates positively with decreasing channel width (fig. 6). The cumulative migration curve for the period 1936-53 shows a relatively steady progression of lateral movement throughout the study reach (figs. 1, 7). The cumulative curve for the period 1953-79 also

\begin{tabular}{|c|c|c|c|c|c|c|}
\hline Year & $\begin{array}{c}\text { Active } \\
\text { channel } \\
\text { surface } \\
\text { area } \\
\left(\mathrm{km}^{2}\right)\end{array}$ & $\begin{array}{c}\text { Newly } \\
\text { eroded } \\
\text { channel } \\
\text { area } \\
\left(\mathrm{km}^{2}\right)\end{array}$ & $\begin{array}{l}\text { Extent of } \\
1936 \\
\text { channel } \\
\text { occupied } \\
\text { by river } \\
\left(\mathrm{km}^{2}\right)\end{array}$ & $\begin{array}{l}\text { Extent of } \\
1936 \\
\text { channel } \\
\text { filled with } \\
\text { sediment } \\
\left(\mathbf{k m}^{2}\right)\end{array}$ & $\begin{array}{l}\text { Extent of } \\
1936 \\
\text { channel } \\
\text { occupied } \\
\text { by river } \\
(\%)\end{array}$ & $\begin{array}{c}\text { Extent of } \\
1936 \\
\text { channel } \\
\text { filled with } \\
\text { sediment } \\
(\%)\end{array}$ \\
\hline 1936 & 26.1 & - & - & - & - & - \\
\hline 1953 & 18.8 & 6.7 & 12.1 & 14.0 & 46.5 & 53.5 \\
\hline 1979 & 11.2 & 5.8 & 5.4 & 20.7 & 20.8 & 79.2 \\
\hline 1992 & 6.3 & 3.5 & 2.8 & 23.3 & 10.8 & 89.2 \\
\hline 1997 & 7.4 & 4.1 & 3.2 & 22.9 & 12.4 & 87.6 \\
\hline 2007 & 3.3 & 1.9 & 1.4 & 24.8 & 5.2 & 94.8 \\
\hline 2010 & 3.0 & 1.9 & 1.2 & 24.9 & 4.5 & 95.5 \\
\hline
\end{tabular}

Active channel area

1936 channel area

Newly eroded channel course

—— Deposits of lateral accretion

Channel course occupied in 1936

Figure 4. Decreasing active channel area divided into segments that were either newly eroded or overlapped 1936 channel course. As active channel migrated laterally, sedimentation progressively increased in 1936 channel by lateral accretion. Disruption of trends in 1997 was likely due to significant and sustained flooding during January and February 1993.

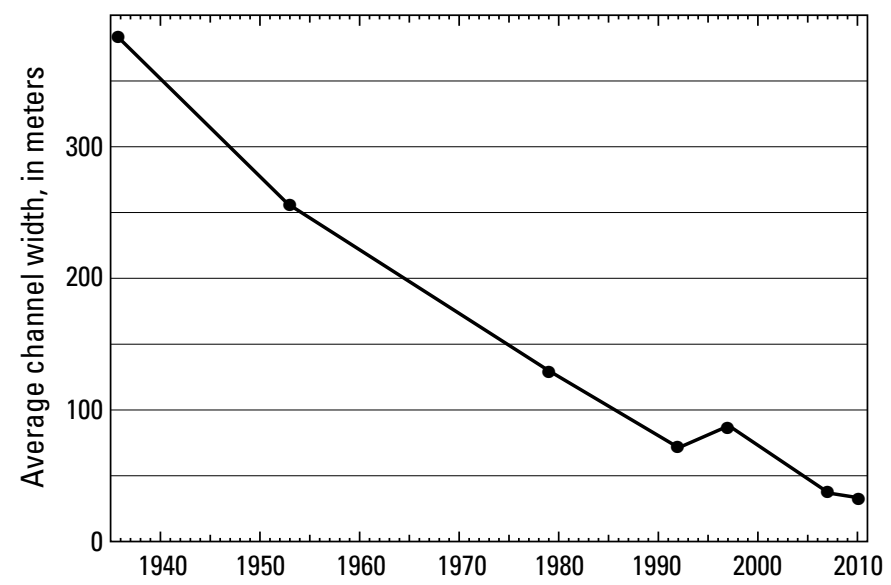

\begin{tabular}{ccccc}
\hline Year & $\begin{array}{c}\text { Average } \\
\text { channel } \\
\text { width } \\
(\mathbf{m})\end{array}$ & $\begin{array}{c}\text { Annualized } \\
\text { change } \\
(\mathbf{m} / \mathbf{y r})\end{array}$ & $\begin{array}{c}\text { Width of prior } \\
\text { measured } \\
\text { channel } \\
(\%)\end{array}$ & $\begin{array}{c}\text { Width of } \\
\mathbf{1 9 3 6} \\
\text { channel } \\
(\%)\end{array}$ \\
1936 & 380.6 & - & - & - \\
1953 & 254.6 & -7.4 & 66.9 & 66.9 \\
1979 & 129.0 & -4.8 & 50.7 & 33.9 \\
1992 & 70.9 & -4.5 & 55.0 & 18.6 \\
1997 & 87.5 & +3.3 & 123.3 & 23.0 \\
2007 & 36.7 & -5.1 & 42.0 & 9.7 \\
2010 & 33.2 & -1.2 & 90.4 & 8.7 \\
\hline
\end{tabular}

Figure 5. Average active channel width. Disruption of trend in 1997 was likely due to significant and sustained flooding during January and February 1993. 


\begin{tabular}{cccc}
\hline $\begin{array}{c}\text { Time } \\
\text { frame } \\
\text { (yrs) }\end{array}$ & $\begin{array}{c}\text { Maximum } \\
\text { centerline } \\
\text { migration } \\
(\mathbf{m})\end{array}$ & $\begin{array}{c}\text { Median } \\
\text { centerline } \\
\text { migration } \\
(\mathbf{m})\end{array}$ & $\begin{array}{c}\text { Annualized } \\
\text { migration } \\
\text { rate } \\
(\mathbf{m} / \mathbf{y r})\end{array}$ \\
$1936-1953$ & 664.7 & 112.3 & 6.6 \\
$1953-1979$ & 836.4 & 75.8 & 2.9 \\
$1979-1992$ & 1616.9 & 38.8 & 3.0 \\
$1992-1997$ & 1932.3 & 18.5 & 3.7 \\
$1997-2007$ & 226.5 & 16.0 & 1.6 \\
$2007-2010$ & 141.6 & 4.0 & 1.3 \\
\hline
\end{tabular}

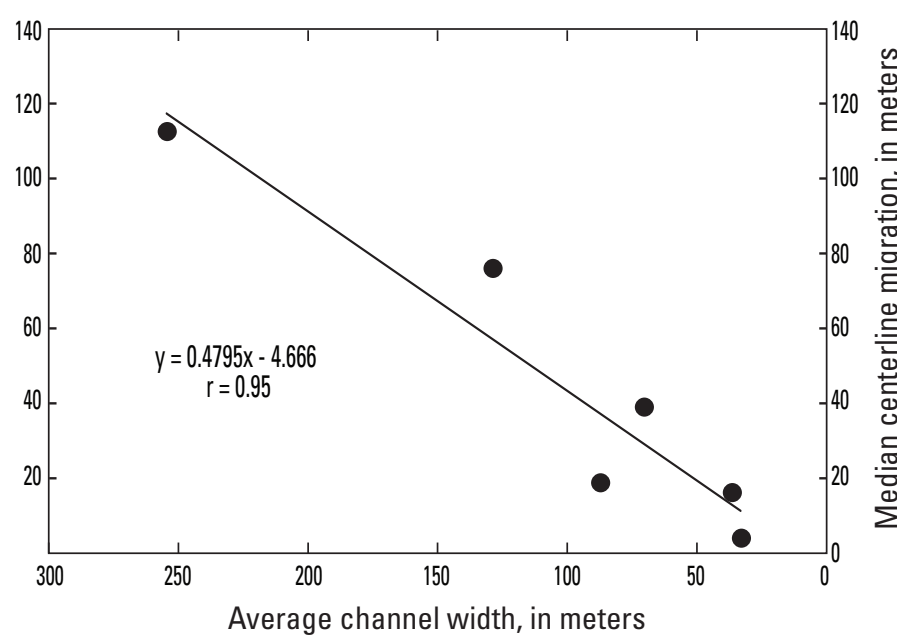

Figure 6. Centerline migration distances and annualized migration rates for the Little Colorado River near Winslow, Ariz. for time frames corresponding to aerial photography. Gray box indicates maximum distance for channel relocation after avulsion. Annualized migration rates are reach averaged and based on median to minimize effect of abrupt channel changes. A decreasing trend is evident, except during periods of avulsion. A significant positive correlation exists between channel width (see fig. 5) and median centerline migration distance.

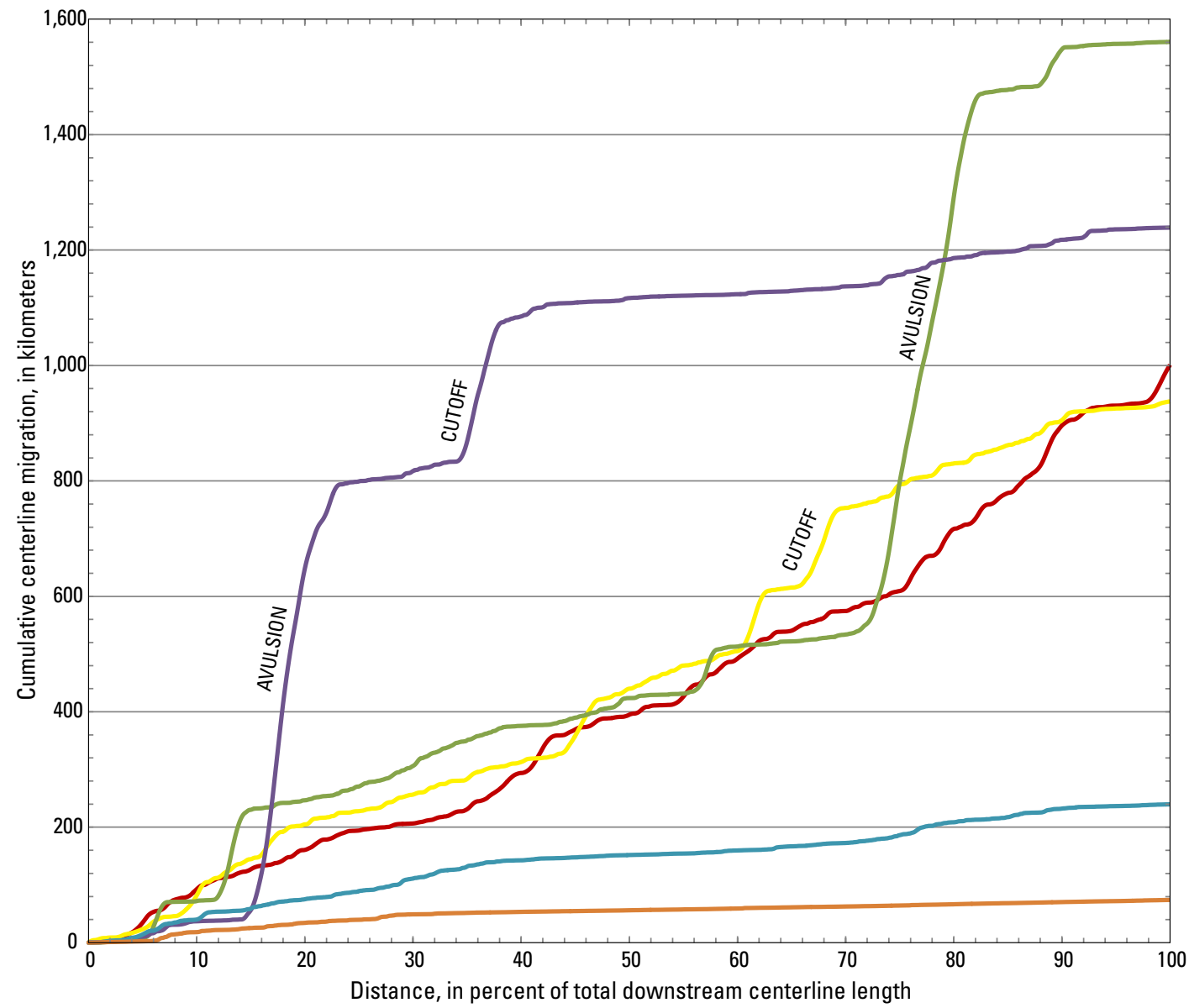

\section{EXPLANATION}

Cumulative Centerline Regression migration length line curve $\quad(\mathrm{km}) \quad$ slope

-1936-53 $69 \quad 14.0$
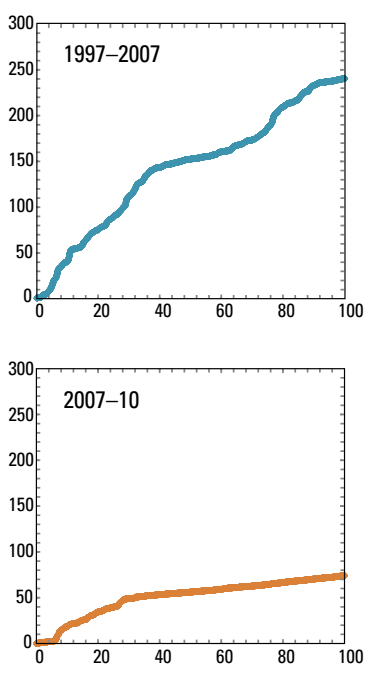

Figure 1. Cumulative centerline migration versus distance along Little Colorado River near Winslow, Ariz. (fig. 1) showing where river was more or less prone to lateral migration. Centerline length is normalized to percentage of total. Steep slopes indicate abrupt change, such as cutoff or avulsion; moderate slopes indicate progressive meandering; and gentle slopes indicate minimal lateral migration. Inset graphs show cumulative curves at an enlarged scale for trend visibility. 
shows a moderate meandering process with a regressionline slope $(\sim 14)$, comparable to the earlier time interval. In contrast to the earlier curve, the cumulative curve for the period 1953-79 shows more frequent and pronounced steps, indicating abrupt channel shifts or cutoffs; and the cumulative curve for the period 1979-92, shows a marked step trend with a conspicuous avulsion. Because the cumulative curve for the period 1979-92 is decidedly nonlinear, a single regression-line slope could not be fitted to it; the channel segment from $\sim 15-55$ percent of the downstream centerline distance is the only reach where moderate channel meandering is occurring and has a slope of 6.5. The cumulative curve for the period 1992-97 shows a stepped trend dominated by an avulsion and a major neck cutoff; the rest of the study reach has a cumulative curve with minimal slope, indicating minor lateral movement. The cumulative curve for the period 1997-2007 shows a steadily increasing slope at the scale of the composite graph. An inset graph, scaled to accommodate the reduced degree of lateral migration, shows distinct zones of activity (fig. 7). The initial $\sim 40$ percent of the channel has a regression-line slope of 4.6 , whereas the next 20 percent of the channel has a regression-line slope of 0.98 , the following 30 percent of the channel has a regression-line slope of 3.5, and the last 10 percent of the channel has a regression-line slope of 0.75 . The cumulative curve for the period 2007-10 is similarly scaled on an inset graph for trend visibility (fig. 7). The initial 5 percent of the channel shows minimal activity, with a regression-line slope of 0.5 . The next $\sim 30$ percent of the channel has a regression-line slope of 1.7 and includes two small steps, and the rest of the channel has a regression-line slope of 0.4. Cumulative centerline migration curves correspond to the channel-migration-ratio map in isolating where the Little Colorado River was more or less mobile between 1936 and 2010 (fig. 8).

Sinuosity of the Little Colorado River in the study area (fig. 1) increased from 1.4 in 1936 to 1.9 in 2010. During that period, two major avulsions and numerous cutoffs occurred. Localized sections of the study reach show high sinuosity before avulsion, suggesting an apparent sinuosity threshold for avulsion. Sinuosity increased until an avulsion occurred, after which sinuosity initially decreased, but then increased again as the channel continued to narrow. Sinuosity was 2.6 and 2.4 for subreaches A and B, respectively, at or near the time of avulsion (fig. 9).

The avulsion in subreach A occurred between 1979 and 1992, likely during the 1980 flood; the avulsion in subreach B occurred between 1992 and 1997, likely during the 1993 flood. Before the channel avulsed to its new $4.8 \mathrm{~km}$ length, numerous cutoffs occurred in the $\sim 10.5-\mathrm{km}$-long channel of subreach A (distance measured from bifurcation to reattachment point). Although no significant cutoffs are evident on aerial photographs before the avulsion in subreach $\mathrm{B}$, a meander-neck cutoff of $\sim 1 \mathrm{~km}$ occurred nearly $2 \mathrm{~km}$ upstream of the bifurcation point. The avulsion in subreach $B$ reduced the channel length from 8.8 to $4.7 \mathrm{~km}$. The two periods that encompass the 1978 and 1993 floods show the most cutoffs in the study reach: $\sim 13$ cutoffs between 1953 and 1979, and $\sim 20$ cutoffs between 1992 and 1997. Cutoffs tend to cluster because each occurrence accelerates local system change (Stølum, 1996).

Measurements of channel-planform change in this study exceed the sum of registration and digitization errors by 78-98 percent for each time step until 2007-10. Because of the narrowness of the channel in 2010, the decrease in peak discharge, and the error margin for the imagery, the annualized average channel-migration rate is approximately equivalent to the annualized error margin. However, 70 percent of the distance measurements are above the annualized error margin, and $\sim 8$ percent of the distance measurements show a lateral migration of $>25 \mathrm{~m}$ over the 3-year interval.

\section{Discussion}

\section{Regional Hydroclimate}

Climate projections are unequivocal in forecasting a warmer and drier Southwest (Seagar and Vecchi, 2010). As concerns over water availability become more pressing, hydroclimatic trends and streamflow timing have been studied extensively (for example, Stewart and others, 2005; Clow, 2009; Vicuna and others, 2011; Hall and others, 2012). In the Western United States, regional storm-precipitation characteristics tend toward a decrease in total mean storm precipitation and mean storm duration, with a concomitant increase in mean storm intensity (Palecki and others, 2005). An increasing fraction of winter precipitation is also falling as rain rather than snow as the climate warms (Knowles and others, 2006). Yet the amount of effective precipitation decreases by $\sim 50 \mathrm{~mm}$ for every $1^{\circ} \mathrm{C}$ rise in temperature in northeastern Arizona (Redsteer and others, 2010). Measurements from 25 sites, including the Little Colorado River Basin, show a decline in total mean annual snowfall since 1931 (Redsteer and others, 2010). Lower snow accumulations in winter mean less snowmelt runoff in spring, whereas higher temperatures are simultaneously causing an earlier onset of snowmelt (Stewart and others, 2005). An intensified water cycle, owing to a warmer atmosphere, can paradoxically heighten the likelihood of both drought and flooding.

General circulation models (GCMs) indicate that both dry and wet extremes of the hydrologic cycle would be intensified as a result of rising temperatures. Extreme seasonal precipitation reversals have recently been observed in Arizona (Goodrich and Ellis, 2008). After the inception of a regional drought in 1996, the historically dry winter of 2005-6 was preceded by record precipitation in 2004-5. This anomalous wet-to-dry reversal has affected the Little Colorado River Basin. The mean deviation of water year (WY) 2005 precipitation from the station average for climate division 2, which includes the Little Colorado River Basin, was $566.5 \mathrm{~mm}$. Three snow telemetry stations recorded precipitation for WY 2005 (October 1, 2004 to September 30, 2005) at 136 percent of the station average and 167 percent of WY 2004 totals. Yet during the next winter, five of Arizona's 


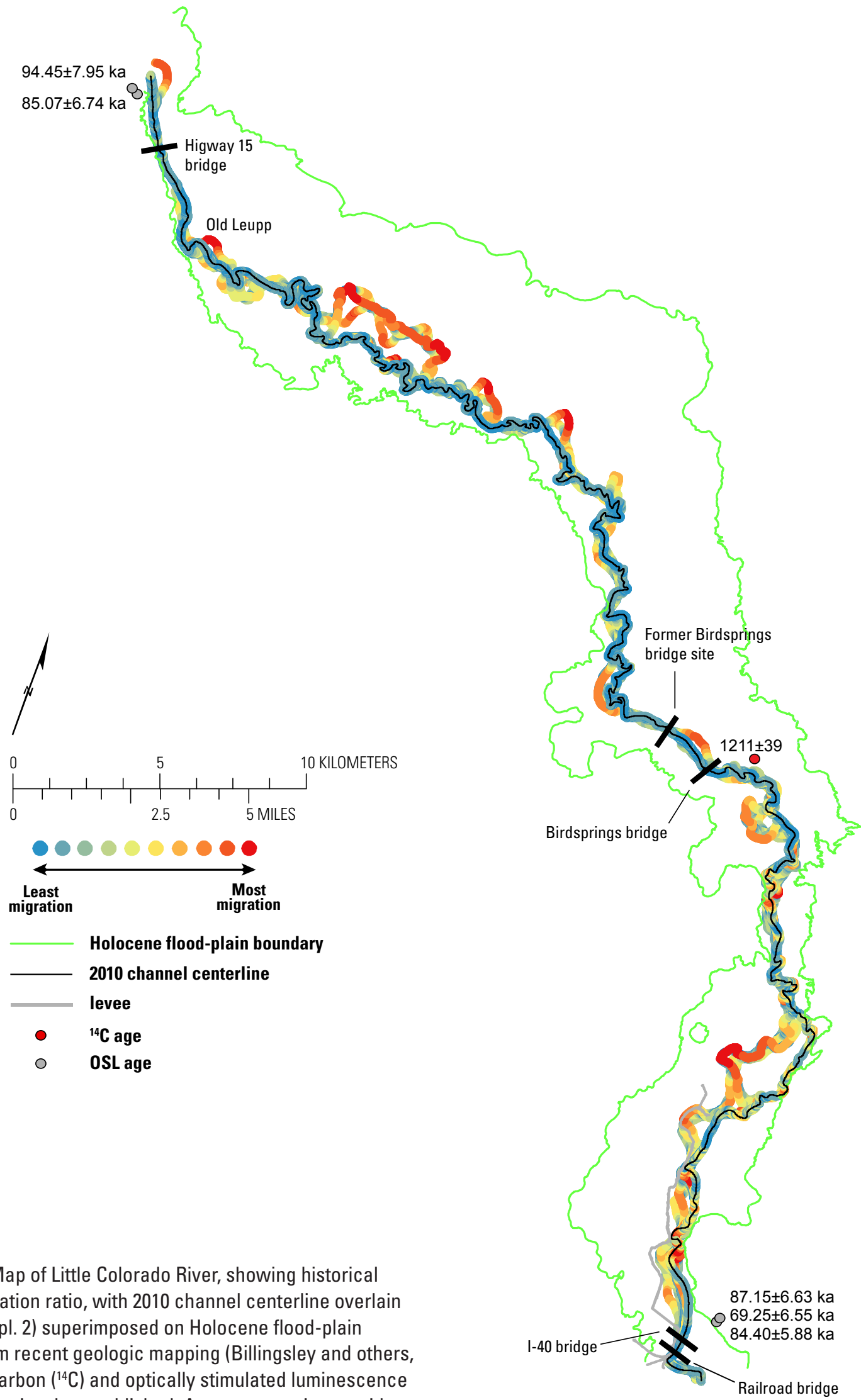

Figure 8. Map of Little Colorado River, showing historical channel-migration ratio, with 2010 channel centerline overlain in black (see pl. 2) superimposed on Holocene flood-plain boundary from recent geologic mapping (Billingsley and others, 2013). Radiocarbon $\left({ }^{14} \mathrm{C}\right)$ and optically stimulated luminescence (OSL) ages previously unpublished. Ages are consistent with geomorphic relations. 


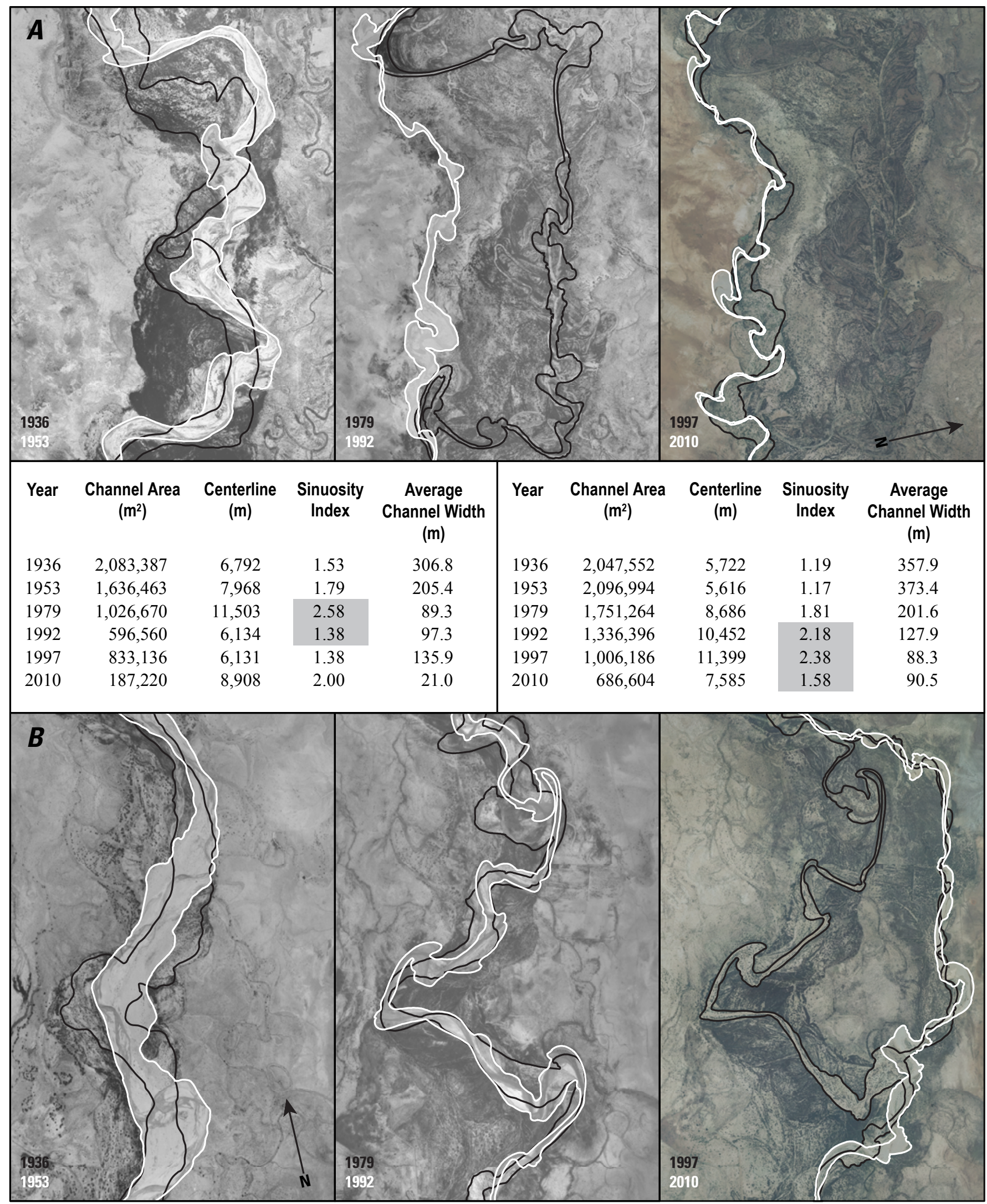

Figure 9. Map showing sinuosity of avulsion zones in Little Colorado River near Winslow, Ariz. Channel area was calculated from geographic-information-system polygons. $A$, Channel segment near Old Leupp; gray box indicates sinuosity before and after avulsion. Date of aerial photographs is same as that of channel (in white). $B$, Channel segment near Winslow; gray box indicates sinuosity of channel before avulsion, of original reach in bifurcated channel, and of channel after avulsion. 
seven climate divisions were categorized as being in extreme drought, as determined by the Palmer Drought Severity Index; the remaining two climate divisions were categorized as being in severe drought. The deviation from the mean for precipitation in climate division 2 was $-362.1 \mathrm{~mm}$ for WY 2006; precipitation recorded at nine stations in the Little Colorado River Basin was 72 percent of the station average and 58 percent of the previous WY totals.

\section{Vegetation and Channel Morphology}

Because the spread of tamarisk generally coincided with a diminishment of native plant communities, it was commonly considered to be the causal agent, although causation remains inconclusive. The effects of tamarisk on the geomorphology of dryland rivers have also been long disputed (for example, Robinson, 1965; Graf, 1978; Everitt, 1980). In general, the spread of tamarisk in riparian corridors of the Western United States is assumed to cause channel constriction through (1) excessive consumption of groundwater or (2) stabilization of biomass density (Graf, 1978). Recent studies, however, indicate that tamarisk transpires equal or less water relative to native species (Nagler and others, 2009). Tamarisk is therefore not likely to substantially affect base flow if the fraction of land surface it covers is similar to that covered by native vegetation. Moreover, some workers have argued that the hydrologic, as opposed to mechanical, effects of riparian vegetation may actually reduce bank stability, particularly in normally unsaturated arid or semiarid channels, where increased infiltration capacity through root macropores may overcome the antecedent soil-moisture deficit (Simon and Collison, 2002).

Other research indicates that vegetation on the outer bank of a meander bend has little significant effect in impeding channel migration (Nanson and Hickin, 1986). Along the Little

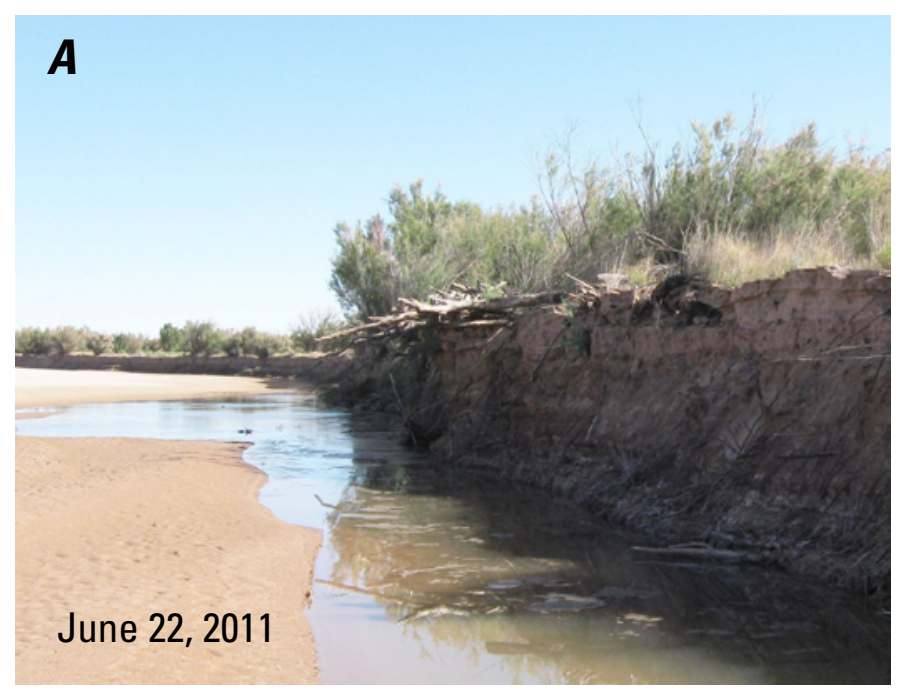

Colorado River in the study area (fig. 1), the process of erosion is relatively insensitive to the spatial distribution or density of vegetation. Despite Huckleberry's (1996) assertion that only extraordinary floods would likely remove the established vegetation on the surface of his units Qa2 and Qa3, established tamarisk thickets were removed by channel erosion even during low to moderate flows (fig. 10).

Hereford (1984) did not interpret vegetation as the driver of channel contraction on the Little Colorado River, although he noted the coincidence of channel narrowing with the spread of tamarisk. Other researchers of contracting dryland ephemeral streams have likewise concluded that channel narrowing was not initiated by the arrival of tamarisk (for example, Everitt, 1998; Cadol and others, 2011). Hereford (1984) attributed $20^{\text {th }}$-century channel narrowing of the Little Colorado River to hydrologic changes due to climate. Because of these changes, the width of channel is reduced, and therefore its flow capacity decreases. Hydrologic changes also affect the establishment of riparian species because plant distributions and successions are mainly controlled by flow magnitude and frequency (Everitt, 1995; Hupp and Osterkamp, 1996; Camporeale and Ridolfi, 2006). Hereford (1984) considered tamarisk germination to be a response to a reduction in discharge and flood frequency. The spread of woody vegetation may be opportunistic, responding to and interacting with other changes in the fluvial environment, including hydrologic and morphologic changes. The recent return of willows to the banks of the Little Colorado River may be evidence of further changes in the hydrologic regime.

\section{Flood Record}

In summer 1923, a USGS-organized expedition under the direction of C.H. Birdseye launched from Lees Ferry to survey the Marble and Grand Canyons. The expedition party camped

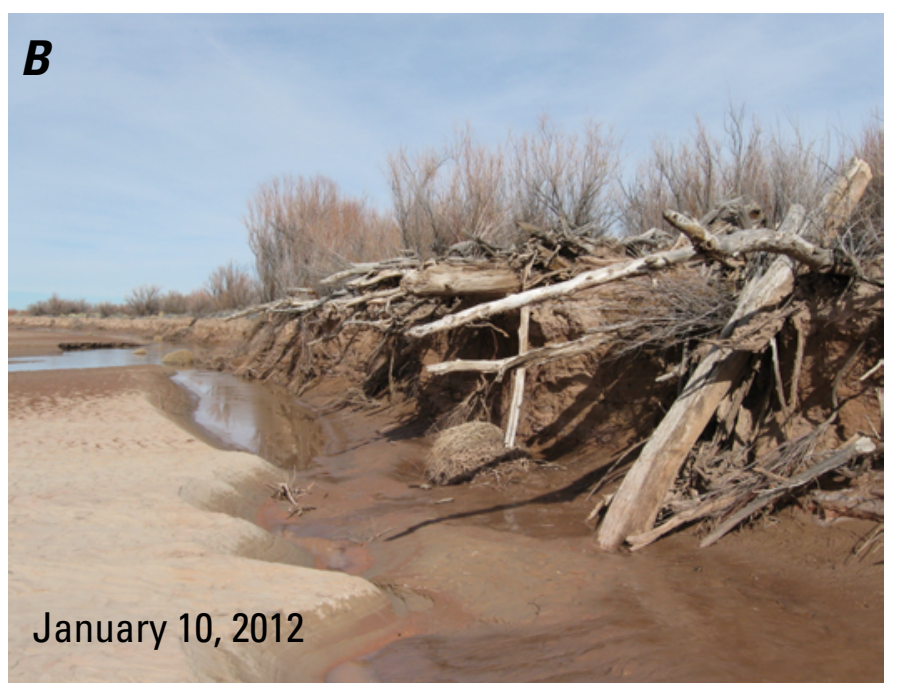

Figure 10. Active meander bend on the Little Colorado River near Winslow, Ariz. (see fig. 1) Silty channel banks are routinely undercut at low to moderate flow velocities. Between photograph dates $(A, B)$, maximum mean daily discharge at streamflow-gaging station near Winslow was 2,400 ft3 $3 / \mathrm{s}$; mean daily discharge was $87.2 \mathrm{ft}^{3} / \mathrm{s}$; and median discharge was $9.2 \mathrm{ft}^{3} / \mathrm{s}$. 
above Lava Falls on the night of September 18; within 24 hours, the Colorado River had risen $\sim 7 \mathrm{~m}$ (Boyer and Webb, 2007). In conjunction with the observed discharges at the streamflowgaging stations at Lees Ferry and Grand Canyon on the Colorado River, the USGS used the high-water mark of $\sim 14 \mathrm{~m}$ from the 1923 flood and the current meter measurement from the 1929 flood $\left(50,500 \mathrm{ft}^{3} / \mathrm{s}\right)$ to estimate a $120,000 \mathrm{ft}^{3} / \mathrm{s}$ peak flow for September 19, 1923, on the Little Colorado River at Grand Falls (Dave Topping, written commun., 2013), the largest documented flow on the river. According to a paleoflood chronology for the Little Colorado River $7 \mathrm{~km}$ downstream of Cameron, slackwater deposits from this flood were higher than all other paleoflood deposits of the late Holocene at this site (Ely, 1997).

The aerial-photographic record is compared with the flood record in table 2. The 1929 flood, with a peak discharge 42 percent of the estimated 1923 peak, is still the extreme flow for the period of record. Aside from discharge measurements, little information is available on flow events during the 1930s through 1970s. A USGS Memorandum of Review notes that the slope-area measurement for the December 20, 1978, flood should be considered poor at best (Howard Matthai, written commun., 1979). On February 20, 1980, the elevation of the water surface was $\sim 2 \mathrm{~m}$ below the Interstate Highway 40 bridge (Don Bills, oral commun., 2013), high enough to cause concern regarding dike failure (Chin and others, 1991). The avulsion at Old Leupp likely occurred during this flood (fig. 9).

In January and February 1993, record precipitation totals generated extreme flow events for many rivers State wide (House and Hirschboeck, 1997). At the streamflow-gaging station at Cameron, the total flow volume for 15 consecutive days (January 10-24, 1993) was greater than the projected 100-year total-flow-volume recurrence interval (Smith and others, 1998). The Little Colorado River was not gaged at Winslow in 1993, and the streamflow-gaging stations on lower Clear Creek and Chevelon Creek were not operating. An indirect measurement of discharge was not made for the 1993 flood at Winslow, owing to insufficient-quality high-water marks (Greg Fisk, written commun., 1994). Five high-water marks on the left bank of the Little Colorado River at Winslow that were flagged after the 1993 flood are, however, $\sim 0.55 \mathrm{~m}$ higher than the 1978 highwater marks. Because the Little Colorado River at Winslow is a sand-bed channel, subject to scour and fill, an estimate of peak discharge through a difference in high-water marks is confounded by the absence of a bed-elevation datum. However, flood discharges at the upper bedrock reaches of Chevelon and Clear Creeks were 19-32 percent higher in 1993 than in 1978, when the calculated peak discharge for the Little Colorado River at Winslow was $57,600 \mathrm{ft}^{3} / \mathrm{s}$ (table 2), suggesting that the peak discharge at Winslow also was higher in 1993.

\section{Channel Response to Flow Events}

Pizzuto (1994) demonstrated how river-channel width can fluctuate, through contraction and expansion, in response to varying discharges. Pizzuto concluded that equilibrium models based on a single channel-forming flow are unsatisfactory for rivers with rapid rates of geomorphic evolution. The equilibrium concept supposes that rivers tend toward establishing a stable relation between channel geometry, discharge, and sediment load. Leopold and Maddock (1953), however, showed that because hydraulic or flow variables (for example, channel width and depth, velocity, particle size, roughness) are continually adjusting to changes in discharge and load, equilibrium cannot be realized. They suggested the term "quasi-equilibrium" to characterize river systems that tend toward, but do not realize, an equilibrium state. In dryland rivers, the spatial and temporal discontinuity of fluvial processes makes the achievement of even approximate equilibrium unlikely (Graf, 1988). For channel width to remain relatively constant, the processes of bank erosion and accretion must be nearly equivalent in time and space.

Historical observations of the Little Colorado River were published in reports on the early geological and geographical surveys of the West. These observations confirm the irregular course of channel evolution there, owing to the highly variable discharge regime common to drylands. At the junction of Diablo Canyon (near Leupp), Whipple (1856) estimated the channel width of the Little Colorado River to be $\sim 18 \mathrm{~m}$ in 1853 ; 5 years later, Ives $(1861$, p. 115$)$ estimated the width of the river at the same point to be $\sim 46 \mathrm{~m}$. In August 1889, Merriam (1890) witnessed torrential rains that produced flash floods cresting at 1.5 to $2.5 \mathrm{~m}$ on Dinnebito and Oraibi Washes after he had crossed a dry riverbed at Grand Falls earlier that month. Heavy rainfall commenced on September 20, 1989, sufficient to create "great lakes... in various parts of the desert, and the Little Colorado bottom was completely flooded. And yet all this vast volume of water disappeared in a few hours." (Merriam, 1890, p. 34).

During an archaeological expedition in 1896, pueblos near Winslow were noted to have been partly washed away on both the left and right banks of the river (Fewkes, 1898). A succession of floods on the Little Colorado River during JanuaryApril 1905 destroyed several large dams that had been built by Mormon settlers in the $19^{\text {th }}$ century (Murphy, 1906). Gregory (1916) described rapid fluctuations in stream volume on the Little Colorado River in the following decade: "In May, 1909, water to the amount of about 300 gallons a minute was flowing over Grand Falls on the Little Colorado. In June the stream was dry; by July 20 it had risen 6 feet and attained in places the width of one-half mile. During the course of fieldwork, July 10-21, 1913, no flowing water was found in the Little Colorado between Sunset Crossing [ $\sim 5 \mathrm{~km}$ downstream of Winslow] and Black Knob [ $\sim 7 \mathrm{~km}$ downstream of Cameron]. At noon on July 21 the water began to rise and by night had reached a stage where crossing was dangerous" (p. 101). Before the age of gage measurements, aerial photography, and GIS, historical reports confirm the variation in flow and geomorphic response of the Little Colorado River.

Aerial photographs were first acquired 13 years after the extreme flow event of 1923 and 7 years after the flood of record. Thus, the 1905, 1923, and 1929 floods preceded the period of channel-planform analysis in this study. The broad 
Table 2. Comparison of aerial photography record with flood record on the Little Colorado River near Winslow, Ariz.

[Discharge recorded at Chevelon Fork below Wildcat Canyon streamflow-gage; gage is $\sim 50$ miles upstream of Little Colorado River confluence. Discharge recorded at Clear Creek below Willow Creek streamflow-gage; gage is $\sim 62$ miles upstream of Little Colorado River confluence. Discharge at Winslow (12/20/1978) estimated by USGS from slope-area measurement at reach beginning $\sim 2,200 \mathrm{ft}$ upstream from railroad bridge and ending $\sim 200 \mathrm{ft}$ upstream of I-40 bridge. Discharge at Winslow (2/20/1980) estimated by USGS from measurements made from I-40 bridge before equipment was lost to the flood and later reconstructed with a measured cross section.]

\begin{tabular}{|c|c|c|c|}
\hline $\begin{array}{l}\text { Aerial photo } \\
\text { interval }\end{array}$ & $\begin{array}{l}\text { Largest peak } \\
\text { discharge(s) in } \\
\text { photo interval } \\
\left(\mathrm{ft}^{3} / \mathrm{s}\right)\end{array}$ & $\begin{array}{c}\text { Streamflowgaging } \\
\text { station }\end{array}$ & $\begin{array}{c}\text { Date of peak } \\
\text { discharge }\end{array}$ \\
\hline-- & 120,000 & -- & $9 / 19 / 23$ \\
\hline 1926-1936 & 50,500 & Grand Falls & $4 / 5 / 29$ \\
\hline 1936-1953 & 38,000 & Grand Falls & $3 / 5 / 38$ \\
\hline \multirow{3}{*}{ 1953-1979 } & 19,900 & Chevelon Fork & $12 / 18 / 78$ \\
\hline & 19,700 & Clear Creek & $12 / 18 / 78$ \\
\hline & 57,600 & *indirect msmt. & $12 / 20 / 78$ \\
\hline 1979-1992 & 28,000 & *indirect msmt. & $2 / 20 / 80$ \\
\hline 1992-1997 & 18,200 & Cameron & $1 / 12 / 93$ \\
\hline 1997-2007 & 20,000 & Winslow & $12 / 30 / 04$ \\
\hline 2007-2010 & 11,200 & Winslow & $1 / 29 / 08$ \\
\hline
\end{tabular}

sandy channel evident in 1936 aerial photographs likely reflects this period of extreme flow events. During field work between Leupp and Cameron in the 1940s, Childs (1948) noted that stream-depositional features were only local and transitory. He stated that the effects of active degradation were unmistakable and that the geomorphic problem was one of erosion. This opinion was upheld by Hereford (1984), who also concluded that erosion was the dominant geomorphic process affecting the morphology of the river channel until the late 1940s or early 1950s.

Flows of high magnitude and prolonged duration are known to produce drastic channel widening in semiarid rivers (Huckleberry, 1994). Some workers consider sustained flooding more likely to affect channel morphology in semiarid regions because the geomorphic effectiveness of flooding is defined partly by slower recovery rates of channelform in these regions (Wolman and Gerson, 1978). Wolman and Gerson emphasized that although rainfall intensities and peak discharges may be similar in different environments, the geomorphic effectiveness of these processes is decidedly dissimilar. Whereas river channels widened by extreme flow events in temperate regions may regain their original width within months or years, river channels widened by extreme flow events in semiarid regions may have recovery rates of decades or longer.

The Little Colorado River presents an ideal case study for investigating the concept of recovery from an extreme flow event. According to Wolman and Gerson (1978), the effectiveness of extreme flow events is relatable to the rate of recovery of channelform. Moreover, they state that the importance of extreme flow events cannot be measured solely in terms of recurrence interval or magnitude of erosion but must be associated with a relative time scale related to climate and vegetation. In other words, the magnitude of a flow event and its effectiveness must be related to the mean conditions of climate and process. Central to their argument of channelform recovery is the amount of moisture available to permit revegetation. They repeatedly assert that the climate in humid regions is what allows for rapid revegetation, thus rapid channelform recovery. In their argument, channelform recovery-that is, narrowingdepends on revegetation. Yet for the Little Colorado River, as discussed above, channel narrowing does appear to be related to climatic conditions, but the decrease in discharge, driven by changes in temperature and precipitation, is what is causing channel narrowing, not the presence or absence of vegetation.

Riparian vegetation does, however, influence channel morphology by increasing the coefficient of roughness, inducing sedimentation during overbank flow (Thorne, 1990). Hereford (1984) determined that the Little Colorado River flood plain aggraded from 1952 to 1978, as vegetation trapped sediment from seven overbank-flow events; but this process did not stop after 1980. Thus, it is not likely that the flood plain became a terrace after 1980, as suggested by Hereford (1984). Moreover, although the 1980 flood may not have overtopped the banks at Tolchico or Cameron, it was only just constrained by the levee at Winslow (Chin, 1991). Several overbank-flow events have occurred since then, and as a result, the flood plain has 
likely aggraded vertically. So, although the dominant pattern of sedimentation may have shifted to lateral accretion in 1980, overbank flow and, thus, vertical accretion still occurs. The thesis that historical erosional and aggradational events along the Little Colorado River occurred simultaneously with climatic changes, however, remains intact.

Hydrographs of daily mean discharge for the 1993, 2004, and 2008 floods are shown in figure 11. Although all three floods overtopped the channel banks, only the 1993 flood widened the channel. The broader peaks and slightly less steep falling limbs for the 1993 flood contrast with the typically sharp peaks and equally steep limbs of $21^{\text {st }}$-century streamflow hydrographs. The persistent duration of flow during the storms of January and February 1993 likely initiated the channel widening evident on 1997 aerial photographs. The temporarily widened channel after the 1993 flood could also explain the exception to an increase in sinuosity for subreach A between 1992 and 1997 (fig. 9). Although the sinuosity index decreased marginally between 1936 and 1953 in subreach B, the sinuosity index for the entire study reach (fig. 1) increased from 1.41 to 1.53 during that interval, in conjuction with channel narrowing. Sustained flows in the future, however, could again widen the channel, which would, in turn, affect sinuosity.

\section{Flood-Hazard Assessment and Mitigation}

Along many rivers, the primary flood-related concern is the hazard associated with inundation, by water overtopping banks or levees. This flood hazard is typically quantified by using hydrologic and hydraulic models, such as HEC-RAS, to identify the probable lateral extent of inundation during selected recurrence intervals. Such models use a fixed channel configuration as a boundary condition, assume that depth and velocity are constant over time at a given point along the channel, and that roughness is homogeneous. The results of these models

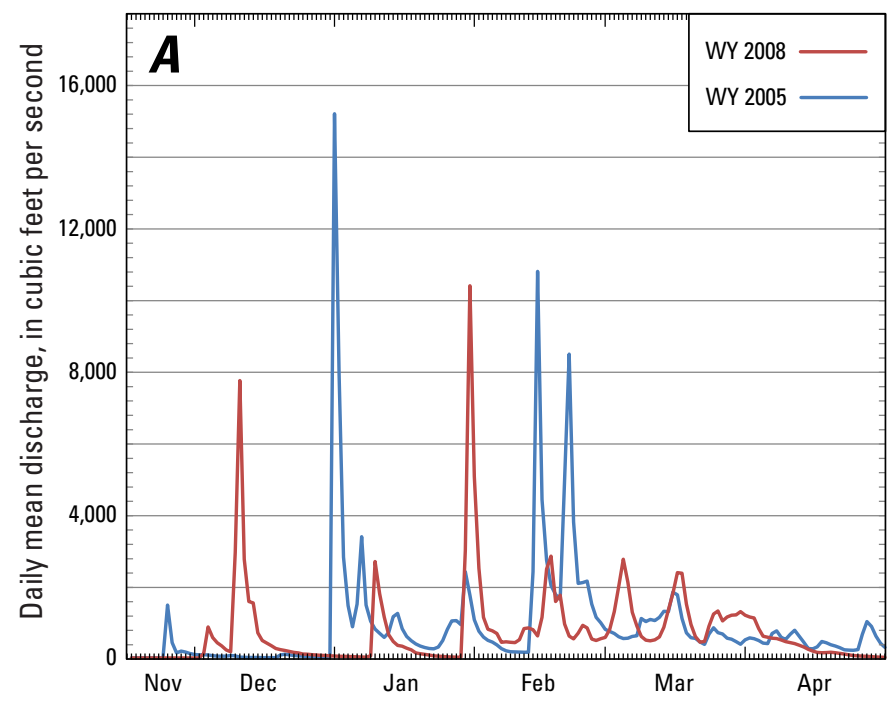

are commonly used to delineate the hydrologic flood plain for insurance, zoning, and other management purposes.

One-dimensional steady-flow models like HEC-RAS, however, are inadequate for dynamic alluvial dryland rivers, such as the Little Colorado. In unstable alluvial dryland rivers, channelform changes and associated erosion may constitute an even-greater flood-related hazard than floodwater inundation (Graf, 1984). Channel adjustments, including lateral migration and channel narrowing, can significantly change the boundary conditions for flooding. The $90-\mathrm{km}$ sand-bed reach of the Little Colorado River in this study has adjusted to flow variability by rapid lateral channel migration and narrowing, neither of which has been considered in previous stability or hazard assessments. Areas susceptible to channel migration are not typically characterized within flood-hazard assessments that rely on delimiting flood-plain-inundation depths and extents, or by floodmitigation plans that emphasize river-engineering projects (for example, levees, channel straightening, and bank stabilization).

Flood-control structures designed to eliminate or reduce flood hazards in the Winslow area (fig. 1) have failed historically. The avulsion in subreach B (fig. 9) is immediately downstream of an $11.5-\mathrm{km}$-long earthen levee that was repeatedly overtopped and breached. A major flood in December 1978 considerably damaged the levee, and a new levee was constructed in 1989. Despite improvements to the levee in 1991, failures occurred during floods in January 1993, January 1995, and December 2003 (Greg Fisk, oral commun., 2008). Although the levee improvements were intended to provide 100-year-flood protection, the peak discharge in each of these floods was well below the predicted 100-year-flood level of $65,000 \mathrm{ft}^{3} / \mathrm{s}$ (Federal Emergency Management Agency, 2008). The site of the 2003 levee failure is at a section built across the 1936 channel.

The Little Colorado River channel has also been straightened and shifted away from the levee, as shown in 1992 aerial photographs (fig. 12). However, human modifications to channels can cause significant morphologic adjustments. Aerial

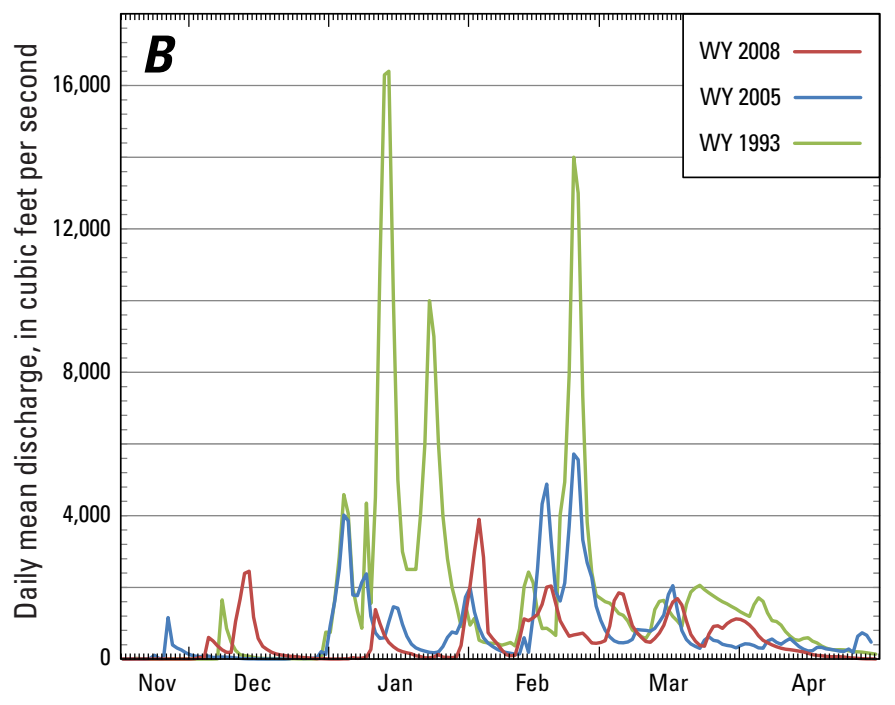

Figure 11. Daily mean discharge at two streamflow-gaging stations on the Little Colorado River, Ariz. A, Near Winslow for December 2004 and January 2008 floods. B, Near Cameron for 1993, 2004, and 2008 floods. Gages are 105 river miles apart. 

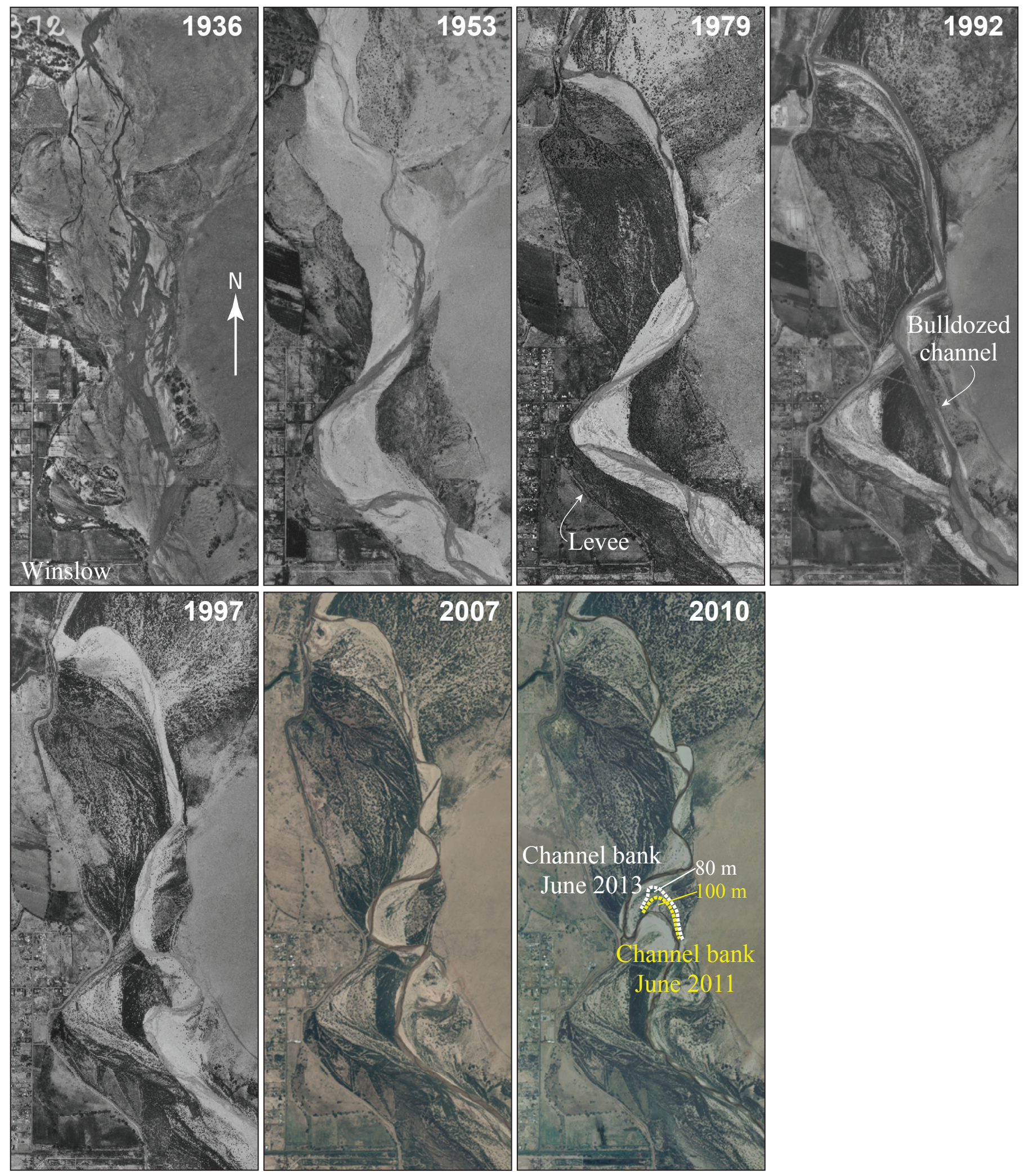

Figure 12. Aerial photographs of Little Colorado River channel near Winslow, Ariz. showing, in addition to changes in channel morphology, human modifications to constrain the river, including an earthen levee and channelization. Levee has been breached repeatedly, and artificially straightened channel was short lived. 
photographs taken in 1997 show erosional and depositional processes reestablished as the previously straightened 1-km-long segment resumed meandering. By 2007, the once-channelized river segment had already cut off its newly developed meander bend, and another meander had begun to form downstream. The jetty at the downstream end of the previously straightened channel reach was damaged by the 2008 flood (table 2).

The Bureau of Reclamation (2003) determined that no sedimentation effects would occur upstream or downstream from either realigning the levee or channelizing a segment of the Little Colorado River. They did, however, recognize that all mapped alluvial deposits adjacent to the levee had formed within the historical record and thus have a high potential for lateral migration. Nonetheless, the U.S. Bureau of Reclamation concluded that a meander flanking the levee and cut into an older Tamarisk alluvium (unit Qa2b) is relatively stable, owing to the dense vegetation on the high bank it is undercutting. Yet the apex of the meander bend had migrated $\sim 55 \mathrm{~m}$ by 2007 and another $\sim 25 \mathrm{~m}$ by 2010 . Also by 2010 , the channel cut off the downstream meander that abutted the levee, moving its left bank $\sim 315 \mathrm{~m}$ vertically or $\sim 360 \mathrm{~m}$ along the levee. This section of the levee cuts across both the 1936 and 1953 channels.

Not only have flood-control measures proved to be ineffective; they also have likely exacerbated the flood hazard to local communities. Between 2007 and 2010, the most laterally active segment of the study reach (fig. 1)-from $\sim 5$ to 32 percent of the downstream centerline length-is adjacent to and immediately downstream of the levee (pl. 2). This segment has a median centerline migration distance twice that of the total reach-averaged migration distance (fig. 6). Also, the newly eroded proportion of the active channel from 2007 to 2010 was 61 percent (fig. 4)-the highest percentage of newly created channel over the study period, even though flows during this period were drastically reduced. On a meander bend in the leveed reach, $\sim 100 \mathrm{~m}$ of erosion occurred over the course of a single year when total precipitation was just 58 percent of the annual mean.

\section{Conclusion}

Continuing changes in hydrologic regime, not simply groundwater withdrawal or vegetation encroachment, have likely caused channel narrowing on the Little Colorado River. Yet localized bank erosion remains hazardous along the study reach of the river (fig. 1), particularly where the river has been artificially confined, even though discharge and channel width have decreased. Morphologic adjustments of the Little Colorado River are seemingly exacerbated by channelization and levee construction, despite increasing aridity and reduced streamflow.

The flood plain below Winslow (fig. 1) also is now subject to inundation at lower discharges, owing to the river's reduced channel capacity. Although no extreme flow events have occurred since 1993, other flows, most notably those during 2004 and 2008, have overtopped the banks. The January 2008 flood, with a peak discharge of $11,200 \mathrm{ft}^{3} / \mathrm{s}$, spread across the flood plain for $>3 \mathrm{~km}$, leaving local transportation routes inaccessible. A total of 12 communities of the Navajo Nation were adversely affected by this moderate-flow event, with a peak discharge that was just 22 percent of the flood of record and 17 percent of the predicted 100-year flood. Changes in channel carrying capacity will affect the calculations of annual exceedance probabilities for floods (Holmes and Dinicola, 2010).

The present study demonstrates the utility of historical analysis for understanding dryland fluvial processes. Geomorphic or landscape-forming processes are complex in drylands, where the concepts of stationarity and equilibrium are particularly unsuitable. According to Milly and others (2008), "In a nonstationary world, continuity of observations is crucial." For example, observations on the Little Colorado River indicate that a decline in peak flow does not necessarily correspond to a decrease in channel hazards, from either migration or inundation. Methodologies more appropriate to the specific hydrologic characteristics of dryland rivers are required for effective water management, including the acquisition of consistent, high-quality, long-term data for successful process studies.

\section{References Cited}

Adams, D.K., and Comrie, A.C., 1997, The North American monsoon: Bulletin of the American Meteorological Society, v. 78 , no. 10 , p. 2197-2213.

Barnett, T.P., Pierce, D.W., Hidalgo, H.G., Bonfils, C., Santer, B.D., Das, T., Bala, G., Wood, A.W., Nozawa, T., Mirin, A.A., Cayan, D.R., and Dettinger, M.D., 2008, Humaninduced changes in the hydrology of the western United States: Science, v. 319, no. 5866, p. 1080-1083.

Billingsley, G.H., Block, D., and Redsteer, M.H., 2013, Geologic map of the Winslow 30' x 60' quadrangle, Coconino and Navajo Counties, northern Arizona: U.S. Geological Survey Scientific Investigations Map 3247, 25 p., 3 sheets, scale 1:50,000, at http://pubs.usgs.gov/sim/3247/.

Block, D., and Redsteer, M.H., 2011, A dryland river transformed - the Little Colorado, 1936-2010: U.S. Geological Survey Fact Sheet 2011-3099, 4 p.

Boyer, D.E., and Webb, R.H., 2007, Damming Grand Canyonthe 1923 U.S. Geological Survey Colorado River expedition: Logan, Utah State University Press, 289 p.

Bradley, C., and Smith, D.G., 1984, Meandering channel response to altered flow regime-Milk River, Alberta and Montana: Water Resources Research, v. 20, no. 12, p. 1913-1920. 
Brown, C.R., and Macy, J.P., 2012, Groundwater, surfacewater, and water-chemistry data from $\mathrm{C}$-aquifer monitoring program, northeastern Arizona, 2005-11: U.S. Geological Survey Open-File Report 2012-1196, 46 p.

Bull, L.J., and Kirkby, M.J., 2002, Dryland river characteristics and concepts, in Bull, L.J., and Kirkby, M.J., eds., Dryland rivers - hydrology and geomorphology of semi-arid channels: Chichester, U.K., John Wiley \& Sons, p. 3-15.

Cadol, D., Rathburn, S.L., and Cooper, D.J., 2011, Aerial photographic analysis of channel narrowing and vegetation expansion in Canyon De Chelly National Monument, Arizona, USA, 1935-2004: River Research and Applications, v. 27 , no. 7 , p. $841-856$.

Camporeale, C., and Ridolfi, L., 2006, Riparian vegetation distribution induced by river flow variability - a stochastic approach: Water Resources Research, v. 42, no. 10, p. W10415.

Childs, O.E., 1948, Geomorphology of the valley of the Little Colorado River, Arizona: Geological Society of America Bulletin, v. 59, p. 353-388.

Chin, E.H., Aldridge, B.N., and Longfield, R.J., 1991, Floods of February 1980 in southern California and central Arizona: U.S. Geological Survey Professional Paper 1494, 126 p.

Clow, D.W., 2009, Changes in the timing of snowmelt and streamflow in Colorado - a response to recent warming: Journal of Climate, v. 23, no. 9, p. 2293-2306.

Colton, H.S., 1937, Some notes on the original condition of the Little Colorado River - a sidelight on the problems of erosion: Museum of Northern Arizona Museum Notes, v. 10, p. $17-20$.

Cooley, M.E., Harshbarger, J.W., Akers, J.P., Hardt, W.F., and Hicks, O.N., 1969, Regional hydrogeology of the Navajo and Hopi Indian reservations, Arizona, New Mexico, and Utah, with a section on Vegetation: U.S. Geological Survey Professional Paper 521-A, $60 \mathrm{p}$.

Dean, D.J., and Schmidt, J.C., 2011, The role of feedback mechanisms in historic channel changes of the lower Rio Grande in the Big Bend region: Geomorphology, v. 126, no. 3-4, p. 333-349.

Downward, S.R., Gurnell, A.M., and Brookes, A., 1994, A methodology for quantifying river channel planform change using GIS, in Olive, L.J., Loughran, R.J., and Kesby, J.A., eds., Variability in stream erosion and sediment transport: International Association of Hydrological Sciences Publication 224, p. 449-456.

Dunne, T., and Leopold, L.B., 1978, Water in environmental planning: San Francisco, Calif., W.H. Freeman, 818 p.
Ely, L.L., 1997, Response of extreme floods in the southwestern United States to climatic variations in the late Holocene: Geomorphology, v. 19, no. 3-4, p. 175-201.

Everitt, B.L., 1980, Ecology of saltcedar-a plea for research: Environmental Geology, v. 3, p.77-84.

Everitt, B.L., 1995, Hydrologic factors in regeneration of Fremont cottonwood along the Fremont River, Utah, in Costa, J.E., Miller, A.J., Potter, K.W., and Wilcock, P.R., eds., Natural and anthropogenic influences in fluvial geomorphology: American Geophysical Union Monograph 89, p. 197-208.

Everitt, B., 1998, Chronology of the spread of tamarisk in the central Rio Grande: Wetlands, v. 18, no. 4, p. 658-668.

Faurès, J.-M., Goodrich, D.C., Woolhiser, D.A., and Sorooshian, S., 1995, Impact of small-scale spatial rainfall variability on runoff modeling: Journal of Hydrology, v. 173, no. 1-4, p. 309-326.

Federal Emergency Management Agency, 2008, Flood insurance study-Navajo County, Arizona and incorporated areas: Washington, D.C., Federal Emergency Management Agency, v. $1,78 \mathrm{p}$.

Fewkes, J.W., 1898, Preliminary account of an expedition to the pueblo ruins near Winslow, Arizona, in 1896, in Annual report of the board of regents of the Smithsonian Institution: Washington, D.C., U.S. Government Printing Office.

Goodrich, D.C., Lane, L.J., Shillito, R.M., Miller, S.N., Syed, K.H., and Woolhiser, D.A., 1997, Linearity of basin response as a function of scale in a semiarid watershed: Water Resources Research, v. 33, no. 12, p. 2951-2965.

Goodrich, G.B., and Ellis, A.W., 2008, Climatic controls and hydrologic impacts of a recent extreme seasonal precipitation reversal in Arizona: Journal of Applied Meteorology and Climatology, v. 47, no. 2, p. 498-508.

Graf, W.L., 1978, Fluvial adjustments to the spread of tamarisk in the Colorado Plateau region: Geological Society of America Bulletin, v. 89, no. 10, p. 1491-1501.

Graf, W.L., 1984, A probabilistic approach to the spatial assessment of river channel instability: Water Resources Research, v. 20 , no. 7 , p. $953-962$.

Graf, W.L., 1988, Fluvial processes in dryland rivers: Berlin, Springer-Verlag, $346 \mathrm{p}$.

Gregory, H.E., 1916, The Navajo country-a geographic and hydrographic reconnaissance of parts of Arizona, New Mexico and Utah: U.S. Geological Survey Water-Supply Paper 380, $219 \mathrm{p}$.

Hack, J.T., 1942, The changing physical environment of the Hopi Indians of Arizona: Cambridge, Mass., Harvard University, Peabody Museum, 85 p. 
Hall, D.K., Foster, J.L., DiGirolamo, N.E., and Riggs, G.A., 2012, Snow cover, snowmelt timing and stream power in the Wind River Range, Wyoming: Geomorphology, v. 137, no. 1, p. 87-93.

Hansen, J., Sato, M., Ruedy, R., Lo, K., Lea, D.W., and MedinaElizade, M., 2006, Global temperature change: Proceedings of the National Academy of Sciences, v. 103, no. 39, p. 14288-14293.

Hapke, C.J., and Reid, D., 2007, National assessment of shoreline change, part 4-Historical coastal cliff retreat along the California coast: U.S. Geological Survey Open-File Report 2007-1133, 51 p.

Harrell, M.A., and Eckel, E.B., 1939, Ground-water resources of the Holbrook region, Arizona: U.S. Geological Survey Water-Supply Paper 836-B, 105 p.

Hart, R.J., Ward, J.J., Bills, D.J., and Flynn, M.E., 2002, Generalized hydrogeology and ground-water budget for the C Aquifer, Little Colorado River basin and parts of the Verde and Salt River basins, Arizona and New Mexico: U.S. Geological Survey Water-Resources Investigations Report 02-4026, $47 \mathrm{p}$.

Helsel, D.R., and Hirsch, R.M., 2002, Statistical methods in water resources techniques of water resources investigations, book 4, Chap. A3: U.S. Geological Survey, 522 p.

Hereford, R., 1984, Climate and ephemeral-stream processestwentieth century geomorphology and alluvial stratigraphy of the Little Colorado River, Arizona: Geological Society of America Bulletin, v. 95, no. 6, p. 654-668.

Hereford, R., Webb, R.H., and Graham, S., 2002, Precipitation history of the Colorado Plateau region, 1900-2000: U.S. Geological Survey Fact Sheet 119-02, 4 p.

Hirschboeck, K.K., 1988, Flood hydroclimatology, in Baker, V.R., Kochel, R.C., and Patton, P.C., eds., Flood geomorphology: New York, Wiley-Interscience, p. 27-49.

Holmes, R.R., Jr. and Dinicola, K., 2010, 100-year flood-it's all about chance: U.S. Geological Survey General Information Product 106, 1 p.

House, P.K., and Hirschboeck, K.K., 1997, Hydroclimatological and paleohydrological context of extreme winter flooding in Arizona, 1993: Reviews in Engineering Geology, v. 11, p. $1-24$.

Huckleberry, G., 1994, Contrasting channel response to floods on the middle Gila River, Arizona: Geology, v. 22, no. 12, p. 1083-1086.

Huckleberry, G., 1996, Geomorphic and stratigraphic dating of recent flood deposits along the Little Colorado River at Winslow, Arizona: report submitted to Aspey, Watkins, and Diesel Attorneys, $10 \mathrm{p}$.
Hughes, M.L., McDowell, P.F., and Marcus, W.A., 2006, Accuracy assessment of georectified aerial photographs - implications for measuring lateral channel movement in a GIS: Geomorphology, v. 74, p. 1-16.

Ives, J.D., 1861, Report upon the Colorado River of the Westexplored in 1857 and 1858: Washington, D.C., U.S. Government Printing Office, $131 \mathrm{p}$.

Jacobson, R.B., and Pugh, A.L., 1998, Riparian-vegetation controls on the spatial pattern of stream-channel instability, Little Piney Creek, Missouri: U.S. Geological Survey Water Supply Paper 2494, 33 p.

Knowles, N., Dettinger, M.D., and Cayan, D.R., 2006, Trends in snowfall versus rainfall in the western United States: Journal of Climate, v. 19, no. 18, p. 4545-4559.

Leopold, L.B., and Maddock, T., 1953, The hydraulic geometry of stream channels and some physiographic implications: U.S. Geological Survey Professional Paper 252, 57 p.

McMahon, T.A., 1979, Hydrological characteristics of arid zones, in The hydrology of areas of low precipitation: International Association of Hydrological Sciences Publication 128 , p. 105-123.

Merriam, C.H., 1890, Results of a biological survey of the San Francisco mountain region and the desert of the Little Colorado, Arizona: Washington, D.C., U.S. Department of Agriculture, Division of Ornithology and Mammalia, 136 p.

Milly, P.C.D., Betancourt, J., Falkenmark, M., Hirsch, R.M., Kundzewicz, Z.W., Lettenmaier, D.P., and Stouffer, R.J., 2008, Stationarity is dead-whither water management?: Science, v. 319, no. 5863, p. 573-574.

Mount, N.J., Louis, J., Teeuw, R.M., Zukowskyj, P.M., and Stott, T., 2003, Estimation of error in bankfull width comparisons from temporally sequenced raw and corrected aerial photographs: Geomorphology, v. 56, p. 65-77.

Murphy, E.C., 1906, Destructive floods in the United States in 1905, with a discussion of Flood discharge and frequency and an index to Flood literature: Geological Survey Water-Supply Paper 162, p. 105.

Nagler, P.L., Morino, K., Didan, K., Erker, J., Osterberg, J., Hultine, K.R., and Glenn, E.P., 2009, Wide-area estimates of saltcedar (Tamarix spp.) evapotranspiration on the lower Colorado River measured by heat balance and remote sensing methods: Ecohydrology, v. 2, no. 1, p. 18-33.

Nanson, G.C., and Hickin, E.J., 1986, A statistical analysis of bank erosion and channel migration in western Canada: Geological Society of America Bulletin, v. 97, no. 4, p. 497-504. 
Neteler, M., and Mitasova, H., 2004, Open Source GIS-a grass GIS approach: Boston, Kluwer Academic Publishers, $424 \mathrm{p}$.

Ollero, A., 2010, Channel changes and floodplain management in the meandering middle Ebro River, Spain: Geomorphology, v. 117, p. 247-260.

Osborn, H.B., Renard, K.G., and Simanton, J.R., 1979, Dense networks to measure convective rainfall in the southwestern United States: Water Resources Research, v. 15 , no. 6, p. 1701-1711.

Palecki, M.A., Angel, J.R., and Hollinger, S.E., 2005, Storm precipitation in the United States. Part I-Meteorological characteristics: Journal of Applied Meteorology, v. 44, no. 6, p. 933-946.

Perşoiu, I., and Rădoane, M., 2011, Spatial and temporal controls on historical channel responses - study of an atypical case - Someşu Mic River, Romania: Earth Surface Processes and Landforms, v. 36, no. 10, p. 1391-1409.

Pizzuto, J.E., 1994, Channel adjustments to changing discharges, Powder River, Montana: Geological Society of America Bulletin, v. 106, no. 11, p. 1494-1501.

Pool, D.R., Blasch, K.W., Callegary, J.B., Leake, S.A., and Graser, L.F., 2010, Regional groundwater-flow model of the Redwall-Muav, Coconino, and alluvial basin aquifer systems of northern and central Arizona: U.S. Geological Survey Scientific Investigations Report 2010-5180, 101 p.

Redsteer, M.H., Block, D., Bogle, R.C., Draut, A.E., Middleton, B., Vogel, J.M., and Velasco, M.G., 2010, Climate change impacts and research on the Navajo Nation, southwestern United States [abs.]: U.S. Geological Survey Climate Change Conference, Denver, Colo., 2010.

Redsteer, M.H., Kelley, K.B., Francis, H., and Block, D., 2010, Disaster risk assessment case study - recent drought on the Navajo Nation, southwestern United States: paper prepared for the 2011 Global Assessment Report on Disaster Risk Reduction: Geneva, Switzerland, United Nations International Strategy for Disaster Reduction, 19 p., at http://www. preventionweb.net/english/hyogo/gar/2011/en/bgdocs/Redsteer_Kelley_Francis_\&_Block_2010.pdf.

Robinson, T.W., 1965, Introduction, spread, and areal extent of saltcedar (Tamarix) in the Western States: U.S. Geological Survey Professional Paper 491-A, 12 p.

Seager, R., and Vecchi, G.A., 2010, Greenhouse warming and the 21 st century hydroclimate of southwestern North America: Proceedings of the National Academy of Sciences, v. 107 , no. 50 , p. 21277-21282.
Simon, A., and Collison, A.J.C., 2002, Quantifying the mechanical and hydrologic effects of riparian vegetation on streambank stability: Earth Surface Processes and Landforms, v. 27, no. 5, p. 527-546.

Sitgreaves, L., 1853, Report of an expedition down the Zuni and Colorado Rivers: Washington, D.C., Robert Armstrong, $198 \mathrm{p}$.

Smith, C.F., Sherman, K.M., Pope, G.L., and Rigas, P.D., 1998, January and February 1993, in Arizona, in Perry, C.A., and Combs, L.J., eds., Summary of floods in the United States, January 1992 through September 1993: U.S. Geological Survey Water-Supply Paper 2499, p. 185-193.

Stewart, I.T., Cayan, D.R., and Dettinger, M.D., 2005, Changes toward earlier streamflow timing across western North America: Journal of Climate, v. 18, no. 8, p. 1136-1155.

Stølum, H.-H., 1996, River meandering as a self-organization process: Science, v. 271, no. 5256, p. 1710-1713.

Thorne, C.R., 1990, Effects of vegetation on riverbank erosion and stability, in Thornes, J.B., ed., Vegetation and Erosion: Chichester, U.K., John Wiley \& Sons, p. 125-144.

Unwin, D.J., 1995, Geographical information systems and the problem of "error and uncertainty": Progress in Human Geography, v. 19, no. 4, p. 549-558.

U.S. Bureau of Reclamation, 2003, Analysis of Little Colorado River stability between Holbrook and Winslow, Arizonareport of findings: Little Colorado River Sediment Study: Denver, Colo., U.S. Bureau of Reclamation, [94] p.

Vicuña, S., Garreaud, R., and McPhee, J., 2011, Climate change impacts on the hydrology of a snowmelt driven basin in semiarid Chile: Climatic Change, v. 105, no. 3, p. 469-488.

Webb, R.H., and Betancourt, J.L., 1992, Climatic variability and flood frequency of the Santa Cruz River, Pima County, Arizona: U.S. Geological Survey Water Supply Paper 2379, $40 \mathrm{p}$.

Webb, R.H., McCabe, G.J., Hereford, R., and Wilkowske, C., 2004, Climatic fluctations, drought, and flow in the Colorado River Basin: U.S. Geological Survey Fact Sheet 2004-3062, 4 p.

Whipple, A.W., 1856, Report of explorations for a railway route, near the thirty-fifth parallel of latitude, from the Mississippi River to the Pacific Ocean, Pacific Railroad Reports: Washington, D.C., U.S. War Department, 136 p.

Wohl, E., Egenhoff, D., and Larkin, K., 2009, Vanishing riverscapes - a review of historical channel change on the western Great Plains: Geological Society of America Special Papers, v. 451, p. 131-142. 
Wolman, M.G., and Gerson, R., 1978, Relative scales of time and effectiveness of climate in watershed geomorphology: Earth Surface Processes, v. 3, no. 2, p. 189-208.

Wolman, M.G., and Leopold, L.B., 1957, River flood plainssome observations on their formation: U.S. Geological Survey Professional Paper 282-C, p. 87-109. 

Menlo Park Publishing Service Center, California

Manuscript approved for publication on June 12, 2014

Edited by George Havach and Kate Burgy

Design and layout by Cory Hurd 
$\underline{\square}$

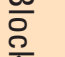

I

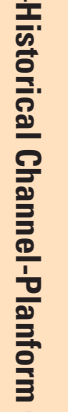

鲇

$\stackrel{\circ}{\rightleftarrows}$

$\overline{\bar{\sigma}}$

둫

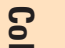

흥

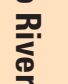

疍

$\sum_{\bar{B}}^{0}$

¿

공.

http://dx.doi.org/10.3133/sir20145112/ 